OPEN ACCESS

Edited by:

Jon Telling,

Newcastle University, United Kingdom

Reviewed by:

Ziming Yang,

Oakland University, United States

Zimin LI,

Catholic University of Louvain,

Belgium

${ }^{*}$ Correspondence:

Martin J. Hodson

mihodson@brookes.ac.uk

Specialty section:

This article was submitted to

Geochemistry,

a section of the journal

Frontiers in Earth Science

Received: 17 December 2018

Accepted: 14 June 2019

Published: 02 July 2019

Citation:

Hodson MJ (2019) The Relative Importance of Cell Wall and Lumen Phytoliths in Carbon Sequestration in Soil: A Hypothesis.

Front. Earth Sci. 7:167.

doi: 10.3389/feart.2019.00167

\section{The Relative Importance of Cell Wall and Lumen Phytoliths in Carbon Sequestration in Soil: A Hypothesis}

\section{Martin J. Hodson* \\ Department of Biological and Medical Sciences, Faculty of Health and Life Sciences, Oxford Brookes University, Oxford, United Kingdom}

There has been much interest in the possibility that phytoliths might sequester substantial amounts of carbon and might continue to do so in soils and sediments after the death of the plant. This may contribute to mitigating climate change. However, this idea is controversial and it is unclear how much carbon is sequestered in phytoliths. High values would suggest that sequestration on a global scale could be significant, but low values would indicate insignificant sequestration. Different methodologies in preparing phytoliths give different carbon concentrations. Little interest has been shown in determining which types of phytoliths are most important for carbon sequestration. There are two main types of phytolith in plants, the cell wall types which are formed on a carbohydrate matrix, and the cell lumen types which are not. A literature survey of transmission and scanning electron microscopy studies to determine which phytoliths are cell wall phytoliths was carried out. Cell wall silicification was common in most plant organs and throughout the plant kingdom. Macrohairs, prickle hairs, and the wall protrusion of papillae are certainly cell wall types. The primary cell walls of many epidermal cells types are often silicified. Cell wall phytoliths have considerably higher carbon concentrations than lumen types. An attempt is made to model mixtures of cell wall and lumen phytoliths, containing different carbon concentrations. Literature data on carbon and nitrogen concentrations in phytoliths was used to produce $\mathrm{C} / \mathrm{N}$ ratios. These showed that cell wall phytoliths had higher $\mathrm{C} / \mathrm{N}$ ratios than lumen phytoliths, and that over-extraction of phytolith mixtures removes carbon preferentially from the cell wall types and leads to low $\mathrm{C} / \mathrm{N}$ ratios. The dissolution of phytoliths in soils and sediments is considered, and it is unknown whether cell wall or lumen phytoliths break down faster. However, it is clear from the literature that cell wall phytoliths persist in soils and sediments for hundreds or thousands of years. The paper is brought to a climax with two hypotheses, one to explain what happens to carbon in phytoliths as they undergo preparatory procedures in the laboratory, and the other looking at dissolution and breakdown in the soil.

Keywords: phytolith, silica, carbon sequestration, cell wall, soil 


\section{INTRODUCTION}

The sequestration of carbon in soils has now become a topic of global significance. It is recognized that soils store very considerable amounts of carbon. If we could find ways of increasing that storage it might go some way toward stabilizing atmospheric carbon dioxide concentrations and thereby help in the fight against climate change. Powlson et al. (2011) pointed out that carbon sequestration in soil suffered from a number of constraints. Firstly, the quantity of carbon stored is finite. Secondly, the process is reversible. Finally soil organic carbon may be increased, but there may be changes in the fluxes of nitrous oxide and methane, important greenhouse gasses.

Parr and Sullivan (2005) first suggested the possibility that phytoliths could play a major part in carbon sequestration in soils. Their proposition was that so-called phytolith occluded carbon (PhytOC) might be locked up in phytoliths for centuries or longer, and not be returned to the atmosphere as quickly as other components of the soil organic matter. So the idea is that carbon sequestered as PhytOC would be less labile, and the reversible nature of sequestration mentioned by Powlson et al. (2011) would be reduced. In their abstract Parr and Sullivan wrote, "Estimated PhytOC accumulation rates were between 15 and $37 \%$ of the estimated global mean long-term (i.e., on a millennial scale) soil carbon accumulation rate of $2.4 \mathrm{~g} \mathrm{C} \mathrm{m}^{-2}$ year $^{-1}$ indicating that the accumulation of PhytOC within soil is an important process in the terrestrial sequestration of carbon." If true, this would be a highly significant finding that could have very major implications for our understanding of the global carbon cycle and for methodologies to reduce global warming. Parr and Sullivan also suggested that it might be possible to select plant species that were particularly high in PhytOC to increase carbon sequestration. Their work stimulated the interest of researchers around the world, and there are now many publications on this topic. However, work on PhytOC has not been without controversy. As, we shall see below this has focused on methodology, with different methods of preparing phytoliths for analysis giving different values for PhytOC. Essentially, if a technique gives a high value for PhytOC then when the value is entered into the equations for estimating global carbon sequestration it will suggest that phytoliths are very important in this process. Conversely, if PhytOC values measured are low then the calculated sequestration at a global scale will be low. This has led to a vigorous debate: what is the "real" value of PhytOC? A related, and even more disputed, area of phytolith research at the moment is the whole topic of "old carbon" from the soil being taken up by plants, and deposited in phytoliths, causing problems in carbon dating. I have covered this area in two recent reviews (Hodson, 2016, 2018) and do not intend to look at it again here.

Phytoliths are morphologically diverse (Madella et al., 2005; Piperno, 2006), but it is becoming increasingly evident that they are also chemically diverse (Hodson, 2016). Kumar et al. (2017b) reviewed the various locations where phytoliths were found in grasses. It appears that silica deposition occurs in all tissues, including the roots, stems, leaves, inflorescence and seed (caryopsis), but that it is concentrated in certain organs and tissues. In the roots, silica is deposited in the endodermis, in the stems, leaves and inflorescence bracts the main deposition sites are in the epidermis, and small amounts are deposited in the seed in brush hairs and other locations. Less work has been done on species other than grasses and cereals, but in general the epidermis in leaves is the major location for most silica deposition (Piperno, 2006). There are three main types of silica deposition in plants: that where silica is deposited onto a carbohydrate matrix such as the cell wall; that where silica deposition lacks an obvious matrix onto which it is deposited, mainly in the cell lumen; and in intercellular spaces (Hodson, 2016). It does not appear that deposition in intercellular spaces is important in the production of recognizable phytoliths that survive once the plant dies, and so the two main types we need to consider are those in the cell walls and the cell lumen. I have previously assessed the evidence that the cell wall and lumen phytoliths have very different chemistries (Hodson, 2016, 2018). Here, we will concentrate on carbon within phytoliths. It would be expected that higher carbon concentrations will be found in cell wall types that are deposited on a carbohydrate matrix, and the evidence available suggests that this is the case.

There has been very little consideration of which phytolith types are the most important for PhytOC and carbon sequestration. This is, perhaps, surprising given the interest in this topic. The aim of this paper will be to bring together the available literature and to assess the relative importance of cell wall and lumen phytoliths in carbon sequestration. I will then develop a hypothesis concerning what happens to phytoliths as they are prepared for analysis and when they enter the soil environment.

\section{A BRIEF HISTORY OF CARBON SEQUESTRATION IN PHYTOLITHS}

Percentage carbon was first measured in phytoliths by Jones and Beavers (1963) who found that those isolated from a Cisne silt loam contained $0.86 \%$ carbon. They were also the first to suggest that carbon was occluded within phytoliths where it is protected from oxidation. For many years after that, papers emerged with varying estimates of the concentration of carbon in phytoliths. Table 1 gives a selection of these publications arranged in date order. It was widely recognized that different methods of preparing phytoliths will give different results, but there was little controversy over this. Usually researchers were using the same method to investigate carbon concentration in a number of species or different organs from the same plant, and they were not comparing their results with other publications that used different methods. Often measuring percentage carbon was incidental to the main focus of the investigation with workers being more interested in carbon dating or carbon isotopes. It was only after Parr and Sullivan (2005) suggested that PhytOC might be important in helping to combat climate change that the controversy really began. It now very much mattered what concentration of carbon was to be found in phytoliths.

As can be seen in Table 1, in all of the early publications the preparatory techniques used by those wishing to measure 
TABLE 1 | Selected examples of \%C measurements in phytoliths.

\begin{tabular}{|c|c|c|c|c|}
\hline Species & Plant organ(s) or soil & $\% \mathrm{C}$ & Preparation method & Authors \\
\hline Various & Soil & 0.86 & Not given & Jones and Beavers, 1963 \\
\hline Various & Grassland soil & 1.3 & Oxidation in cold hydrogen peroxide & Wilding, 1967 \\
\hline Various & Grassland plants & 1.2 & Wet ashing followed by boiling in hydrogen peroxide & Kelly et al., 1991 \\
\hline Various & N. Minnesota sediment & $0.1-0.6$ & Wet ashing followed by warm hydrogen peroxide & Mulholland and Prior, 1993 \\
\hline Sugarcane & Shoot & 3.0 & Microwave digestion & Parr and Sullivan, 2005 \\
\hline Various & Soil & $0.032-5.05$ & Microwave digestion & Parr and Sullivan, 2005 \\
\hline Wheat & Shoot & 1.65 & Dry ashing followed by boiling in hydrogen peroxide & Hodson et al., 2008 \\
\hline Sugarcane cultivars & Shoot & $3.88-19.26$ & Microwave digestion & Parr et al., 2009 \\
\hline Grass and soil & Shoot and soil & $<0.1$ & Wet ashing (plant material) & Santos et al., 2010 \\
\hline Bamboo species & Leaves & $1.6-4.0$ & Microwave digestion & Parr et al., 2010 \\
\hline Wheat cultivars & Leaves and stem & $1.3-12.9$ & Microwave digestion & Parr and Sullivan, 2011 \\
\hline Millet species & Shoot & $0.88-4.78$ & Wet ashing & Zuo and Lü, 2011 \\
\hline Rice cultivars & Stem, leaf, sheath, and grains & $1.4-3.4$ & Microwave digestion & Li et al., 2013b \\
\hline Festuca arundinacea & Leaves & 0.51 & Wet ashing & Alexandre et al., 2016 \\
\hline Durum wheat and sorghum & Leaves & Up to 0.3 & A variety of wet and dry ashing protocols & Reyerson et al., 2016 \\
\hline
\end{tabular}

PhytOC involved either wet ashing or dry ashing, and those are still the preferred methods for many workers. Essentially, wet ashing involves digestion of the plant material in strong acids and/or treatment with strong oxidizing agents such as hydrogen peroxide. In dry ashing, plant material is heated in a muffle furnace to a suitable temperature (often around 450$500^{\circ} \mathrm{C}$ ), that will burn off the surrounding organic matter without damaging the phytoliths. The third method, microwave digestion, was first introduced by Parr et al. (2001). Parr and Sullivan (2014) compared wet ashing and microwave digestion, preferring the latter, as it kept more organic matter within certain classes of phytoliths (see below). A number of wet and dry ashing techniques were investigated by Corbineau et al. (2013), and all had some advantages and disadvantages. It would be fair to say that there is no consensus among scientists over which is the best method, and this has contributed to our problems in determining the "correct" value for PhytOC.

Parr, Sullivan and their co-workers set a firm basis for work on carbon sequestration in phytoliths. Importantly, they were able to show considerable differences between PhytOC in phytoliths from different sugarcane cultivars (Parr et al., 2009), bamboo species (Parr et al., 2010), wheat cultivars (Parr and Sullivan, 2011) and rice cultivars (Li et al., 2013b). Likewise, Zuo and Lü (2011) showed variation in PhytOC in different millet species. More recently, Sun et al. (2017) carried out an extensive survey of carbon sequestration in 51 rice cultivars, finding that there were significant differences between the amounts sequestered by different cultivars. All this work opens up the possibilities of planting certain species or cultivars which will increase carbon sequestration, and of breeding for this trait.

The work of Parr and Sullivan has been followed up and extended in China, mainly by Zhaoliang Song and his group. They have been particularly concerned to measure the potential for carbon sequestration in different environments in China: grasslands (Song et al., 2012a); wetlands (Li et al., 2013a); forests (Song et al., 2013); bamboo forests (Huang et al., 2014); and croplands (Song et al., 2014). In addition the group produced a number of reviews where they considered carbon sequestration at a global scale (e.g., Song et al., 2012b).

It seemed that the idea that phytoliths could sequester substantial amounts of carbon, and thereby help in combatting global warming, was becoming well established, but then Alexandre, Santos and their co-workers produced a series of papers reporting much lower values for PhytOC in their analyses (Santos et al., 2010; Alexandre et al., 2015, 2016; Reyerson et al., 2016). Like most of these papers Reyerson et al. (2016) concentrated on the "old carbon" hypothesis, but they did have a short paragraph looking at carbon sequestration in phytoliths. There they took the maximum PhytOC value that they found in their work $(0.3 \%)$, and a phytolith stability factor of $10 \%$ (Alexandre et al., 2011), and calculated global annual carbon sequestration at $4.1 \times 10^{4} \mathrm{tC}_{\text {year }}{ }^{-1}$. This is around 100 times lower than the $3.7 \times 10^{6} \mathrm{tC}_{\text {year }}^{-1}$ suggested by Song et al. (2014). If Reyerson et al. (2016) are correct then the amount of carbon sequestered in phytoliths would be insignificant on a global scale.

The controversy came to a peak with the publication of two papers in Earth-Science Reviews in 2016 and 2017. Firstly, Song et al. (2016) reviewed the topic from their viewpoint, and then Santos and Alexandre (2017) responded with an almost point by point rebuttal. Song et al. then wrote a reply to Santos and Alexandre (2017), but this was soon "temporarily withdrawn" by Earth-Science Reviews in early 2017, and that remains the case (in June 2019). Clearly there are serious problems here, and it is a great pity that very good scientists have ended up in such a heated debate. I will not take sides here, but try to reconcile the conflicting opinions, and to introduce some new thinking which might help sort out a rather unfortunate situation. Where is the main point of contention? Song et al. (2016) and Santos and Alexandre (2017) disagree on a number of topics, and some of these will be touched on later, but the main one is undoubtedly the true concentration of carbon in phytoliths. Song et al. (2016) routinely use a figure of $3 \%$ for PhytOC, and Santos and Alexandre (2017) think this is too high and that the figure should 
be $0.1-0.5 \%$. The technique of extraction used by Song et al. (2016) is the microwave digestion technique developed by Parr et al. (2001), and Santos and Alexandre worry that this may leave organic contaminants on the surface of extracted phytoliths. The methods of preference for Alexandre, Santos and their coworkers are described in Corbineau et al. (2013), and involve dry ashing and acid digestion or alternatively acid digestion and alkali immersion. They then strongly advise checking the samples with scanning electron microscopy (SEM) and x-ray microanalysis for particles that have high $\mathrm{C} / \mathrm{Si}$ ratios, and discarding those that have, thus eliminating contamination. Song et al. (2016) consider that the low PhytOC values preferred by Santos and Alexandre (2017) are caused by oxidation and over-extraction.

We appear to have reached an impasse with highly respected researchers taking up very entrenched positions. In the past this whole argument would not have happened, but it is now very important that we can determine PhytOC accurately if we are to assess its importance in carbon sequestration. The problem is that it is very difficult to obtain totally clean phytolith preparations without extracting some of the carbon from inside the structures. This may be even more difficult for cell wall phytoliths (see below). So I am uncertain that we will ever be able to give an exact figure for PhytOC, except in very rare circumstances. It is probably safer to give a range of potential concentrations for PhytOC, and to calculate carbon sequestration using a number of values. We should also remember that all the values in Table 1 are estimates of the amount of carbon that is sequestered fairly tightly within the structure of the phytolith. How do they relate to the situation in the soil? Moreover, all of the data in Table 1 are for mixtures of cell wall and lumen phytoliths. As, we shall see below the presence of two phytolith types with very different chemistries complicates matters even more.

\section{LUMEN AND CELL WALL PHYTOLITHS}

Over many years of working on phytoliths I have talked with numerous scientists, seen many conference presentations, reviewed many papers, and read a lot more. I have noticed that some scientists concentrate on cell wall phytoliths and others on lumen phytoliths, and that this at least partly depends on the discipline of the scientist. Chemists and plant scientists have mostly worked on cell wall phytoliths and have a greater interest in what happens in the cell wall. It is possible that the chemists (e.g., Currie and Perry, 2007; Exley, 2015) prefer working on cell wall phytoliths because they have a matrix for deposition which makes the chemistry more interesting. The plant scientists (e.g., Coskun et al., 2018) see many important processes happening in the cell wall including transport, detoxification of metals and defense against pathogens. On the other hand, archeologists, palaeoecologists, and biogeochemists have sometimes seemed to downplay the significance of cell wall types, probably because of their perceived low stability in soils and sediments. For example, Song et al. (2017) stated that, “...C (carbon) from cell wall phytoliths may be quite labile and easily lost at an annual-decadal scale compared to $\mathrm{C}$ trapped in lumen phytoliths, which are likely to be much more stable at a centennial-millennial scale..." The otherwise excellent review of phytoliths in palaeoecology by Strömberg et al. (2018) paid almost no attention to cell wall phytoliths, even when considering the factors likely to increase the dissolution of phytoliths in soils and sediments.

If we are to understand this topic it is important that we have a clear idea of which phytoliths are cell wall types and which are lumen types. This can seem a simple question to answer, but experience suggests that it is not that easy, particularly just using light microscopy. Madella et al. (2005) gave us a nomenclature to classify phytoliths according to their morphology, but there was no mention of their chemistry as this was not the focus of the paper. In Table 2, I present some selected studies using transmission electron microscopy (TEM), where it is easy to determine which phytoliths are cell wall types and which are from the lumen. In TEM silica appears as electron opaque deposits, and the presence of silicon can be confirmed by x-ray microanalysis. In the context of this paper we are most interested in cell wall phytoliths, and that will bias the selection of publications in this section. The additional bias is that most of this work has been on grasses and cereals. The other methodology that is useful in some circumstances uses SEM in tandem with $\mathrm{x}$-ray microanalysis (Table 3). Using SEM it is not always easy to distinguish between cell wall and lumen phytoliths and I have excluded any observations that I felt were uncertain from Table 3.

To facilitate further discussion it is helpful at this point to be able to visualize the different types of phytolith and how they develop. Figure 1 showing five potential pathways of phytolith development. In Figure 1A only the primary cell wall is silicified, whilst in Figure 1B secondary cell walls develop to almost fill the lumen and silica is then deposited on them. In the third type (Figure 1C), silica is deposited in the space between the primary cell wall and the protoplast, and eventually this fills the lumen. In Figure 1D the protoplast breaks down and silica is subsequently deposited within the lumen, entrapping some organelles and membranes. Finally, in Figure 1E silica is first deposited in part of the primary cell wall, and this later grows into the lumen. These five types are not exclusive, and other types are possible. For example, in some cases both the primary (Figure 1A) and secondary (Figure 1B) cell walls are silicified. It is also possible for silicification to begin in the primary wall as in Figure 1E, and to continue into the space between the wall and the protoplast as in Figure 1C.

Almost all of the work on silica deposition in roots has concerned grasses and cereals. There seem to be two main types of deposition. In the roots of Phalaris canariensis (Hodson, 1986) and wheat (Hodson and Sangster, 1989) the cell walls of the endodermis become silicified (as in Figure 1A). The sorghum root has been the most studied system, and here deposition begins in the inner tangential wall of the endodermis and the deposit then grows into the space between the wall and the protoplast (Sangster and Parry, 1976). So part of the deposit is on a carbohydrate matrix and part is not (similar to Figure 1E). In general there have been few reports of silica deposition in tissues of the root other than the endodermis. 
TABLE 2 | Some publications that have used transmission electron microscopy to investigate phytoliths.

\begin{tabular}{|c|c|c|c|c|}
\hline Species & Plant organ & Cell wall phytoliths & Lumen phytoliths & Authors \\
\hline Wheat & Root & Endodermis & & Hodson and Sangster, 1989 \\
\hline Sorghum & Root & Endodermis & & Sangster and Parry, 1976 \\
\hline Wheat & Culm & Epidermis & & Gartner and Paris-Pireyre, 1984 \\
\hline Wheat & Leaf blade & Epidermal long cells and subepidermal sclerenchyma & Silica cells & Hodson and Sangster, 1990 \\
\hline Rice & Leaf & Outer walls of epidermis, papillae & Silica cells, long cells, bulliform cells. & Kaufman et al., 1985 \\
\hline Dactylis glomerata & Leaf & & Silica cells & Laue et al., 2007 \\
\hline Phalaris canariensis & Lemma & Epidermal long cells, macrohairs & & Hodson et al., 1984 \\
\hline Phalaris canariensis & Glume & Macrohairs, prickle hairs, papillae (wall) & Silica cells, papillae (lumen) & Hodson et al., 1985 \\
\hline Setaria italica & Caryopsis & Aleurone and pericarp & & Hodson and Parry, 1982 \\
\hline Wheat & Caryopsis & Epicarp hairs & & Parry et al., 1984 \\
\hline Urtica dioica & Leaf & Stinging emergence (hair) & & Thurston, 1974 \\
\hline
\end{tabular}

TABLE 3 | Some publications that have used scanning electron microscopy and x-ray microanalysis to investigate phytoliths.

\begin{tabular}{|c|c|c|c|c|}
\hline Species & Plant organ & Cell wall phytoliths & Lumen phytoliths & Authors \\
\hline Phalaris canariensis & Root & Endodermis & & Hodson, 1986 \\
\hline Wheat & Root & Endodermis & & Hodson and Sangster, 1989 \\
\hline Wheat & Culm & Epidermis & & Gartner and Paris-Pireyre, 1984 \\
\hline Avena sativa & Inflorescence bracts & Trichomes, long cells. & Silica cells & Kaufman et al., 1972 \\
\hline Equisetum hyemale & Internodes & Epidermis: stomata, papillae, long cells & & Kaufman et al., 1973 \\
\hline Cannabis sativa & Various shoot organs & Hairs & & Dayanandan and Kaufman, 1976 \\
\hline Picea glauca & Needle & Hypodermis and endodermis & & Hodson and Sangster, 1998 \\
\hline Pteridium aquilinum & Petiole & Epidermis & & Parry et al., 1985 \\
\hline
\end{tabular}

It seems that almost all of the silica deposition in grass culms (stems) is in the outer tangential wall of the epidermis (Gartner and Paris-Pireyre, 1984; Hodson, 1986; Hodson and Sangster, 1990). Figure 2 shows a light micrograph of epidermal silicification from the wheat culm in a dry ashed preparation. The cells form a complete sheet or silica skeleton, and the long and short cells all have thin silicified walls similar to the situation in Figure 1A.

Silicification of grass and cereal leaves is quite varied, with both lumen deposition in silica cells and elsewhere, and silica deposition in the cell walls. There has been much attention given to the silica cells (e.g., Kaufman et al., 1985; Hodson and Sangster, 1990; Laue et al., 2007). Kumar et al. (2017a) investigated the development of silica cells in sorghum leaves, and found that the deposits developed in the apoplastic space between the cell wall and the protoplast (see Figure 1C).

The inflorescence bracts of grasses and cereals have received some consideration. In the 1980s three groups all worked on the macrohairs from the lemma of $P$. canariensis, and Hodson et al. (1984) looked at the development of the highly thickened and silicified hairs. By maturity the hairs had only a very small lumen, and the whole wall was silicified. The long cells of the outer epidermis also considerably thickened during development, and silica was then deposited in the thickened cell wall (see Figure 1B). So in this case, what appeared to be a lumen phytolith was actually a cell wall phytolith. In the Phalaris lemma almost all phytoliths isolated from the organ were cell wall phytoliths. It is important to note that using light microscopy and SEM on this system did not indicate that these long cells were cell wall phytoliths, and that the silica was deposited on a carbohydrate matrix (Sangster et al., 1983). It is not always easy to be sure whether a phytolith has such a matrix. Long cells are very important repositories for silica in the epidermis. How many other apparently lumen types are in reality cell wall phytoliths? The Phalaris glumes, the next layer of bracts outside the lemma, are a completely different structure, with silica cells, and several different types of wall phytolith (Hodson et al., 1985).

There has been less work on silica deposition in the grass caryopsis (seed), and where present the amount is low (Hodson and Parry, 1982; Parry et al., 1984). I have included a few examples of work on silica deposition in non-grass species in Tables 2, 3: nettle, Equisetum, Cannabis, white spruce, and bracken. Recently, phytolith production in the bryophytes has also been investigated (Thummel et al., 2018), and most silica deposition seems to be in the cell walls of these plants. It seems that there is little epidermal lumen deposition outside the grasses.

This survey has, of necessity, been brief and I have left out many papers and just selected a few examples. We can conclude that the following phytoliths are definitely cell wall types: macrohairs, prickle hairs, papillae (wall). The cell walls of many epidermal cell types are often silicified, and not only in the grasses. It seems that there are some organs where cell wall silicification is the only type (e.g., grass roots and culms). Cell lumen deposition, particularly in the epidermis, is apparently more common in grasses and cereals than in the rest of the plant kingdom. Whilst it is not possible from this survey to quantify the relative importance of cell wall and lumen phytoliths it is clear that the former make up a very significant proportion of the total. 


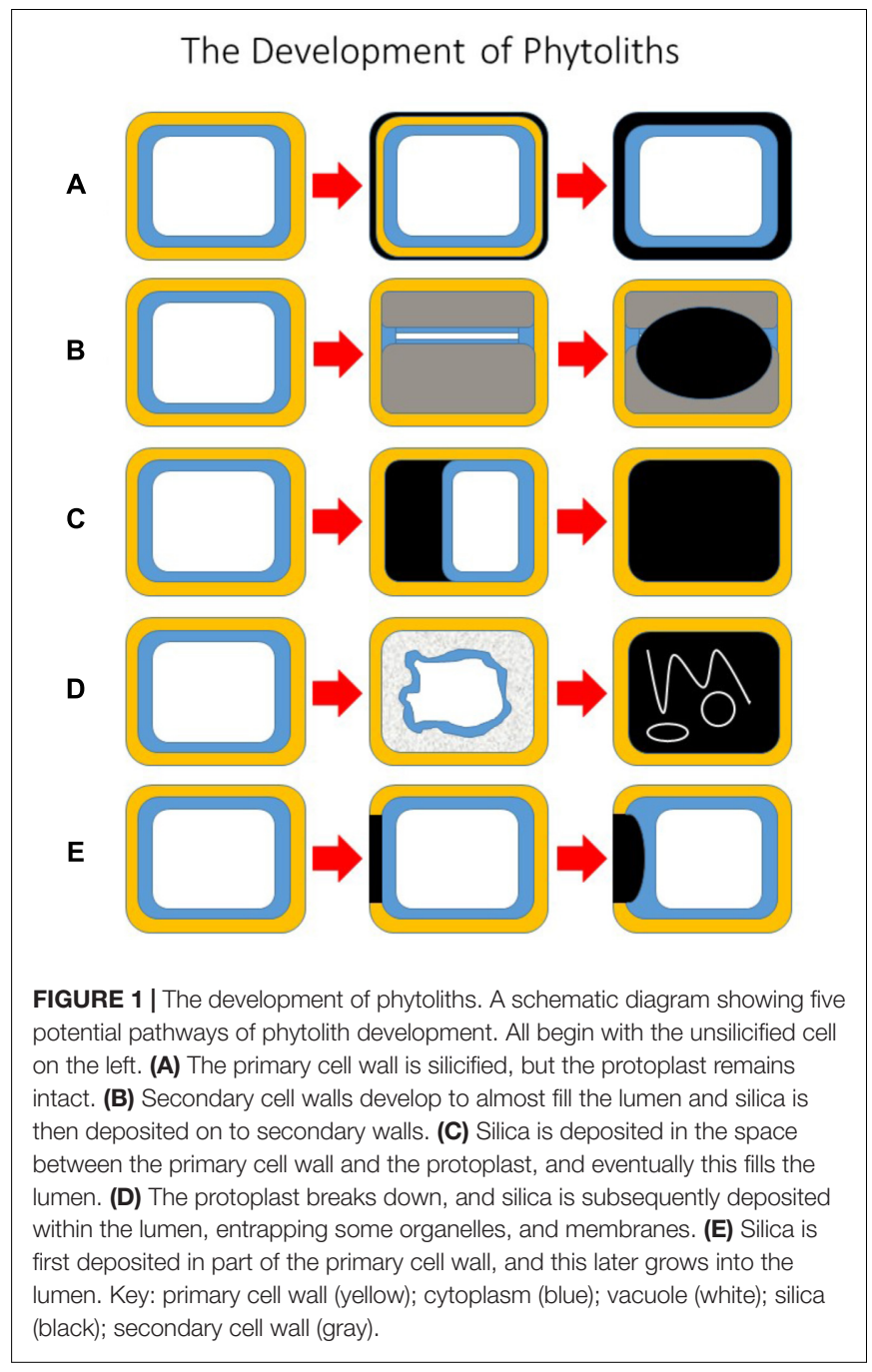

\section{MODELING CARBON IN PHYTOLITHS}

So far, we have seen that there is carbon in phytoliths, and that the amounts reported vary depending both on the sample analyzed and on the technique used to process the phytoliths. We have tried to determine precisely which phytoliths develop as silica is laid down onto a carbohydrate cell wall, and which are not. In this section we will use data that is available in the literature in an attempt to partition PhytOC between cell wall and lumen phytoliths. We will begin with cell wall phytoliths.

Perry et al. (1987) found that the macrohairs from the lemma of the grass, P. canariensis, consisted of $40 \%$ silica, $55 \%$ carbohydrate, and less than $5 \%$ protein. This is the only analysis of native cell wall phytoliths that I am aware of. It is an unusual situation where there are considerable amounts of large silicified hairs that are easy to harvest, and by maturity they consist only of cell wall phytoliths (Hodson et al., 1984). For our purposes, we need to convert the percentages for carbohydrate and protein to percentage carbon. So for $55 \%$ carbohydrate we multiply by $12 / 30$ to obtain a value of $22 \%$ carbon. Let us then assume that the whole of the remaining $5 \%$ organic material is protein. Most

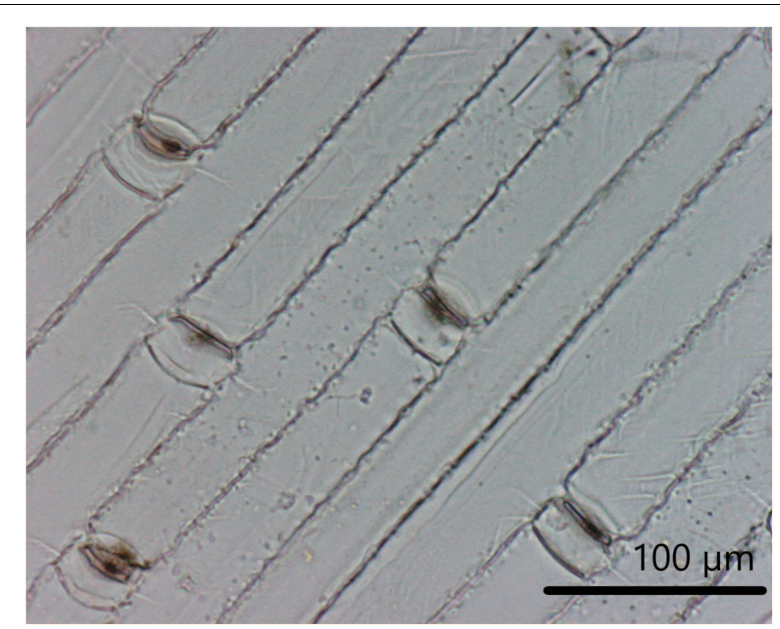

FIGURE 2 | Epidermal silicification from the wheat culm. A light micrograph of epidermal silicification from the wheat (Triticum aestivum L. Cv. Brock) culm in a dry ashed preparation (Buchanan and Hodson, unpublished).

proteins consist of about $53 \%$ carbon. So the proteins in the Phalaris macrohair account for about $2.65 \%$ carbon. The overall PhytOC in these hairs is therefore $24.65 \%$. This value may or may not be typical for cell wall phytoliths, but we would expect that these phytoliths would have significantly higher carbon than lumen phytoliths. Thus, we have PhytOC for native cell wall phytoliths before any treatment to remove carbon (e.g., wet or dry ashing or microwave digestion) or degradation in the soil. This is uncommon as all other literature analyses are for phytoliths that have been treated in some way to remove external carbon. It is also important to note that all of the values quoted in Table 1 above represent those obtained from mixtures of cell wall and lumen phytoliths, and are bound to be lower than those for pure cell wall preparations.

We do not have similar data for native lumen phytoliths, but the percentage of carbon will undoubtedly be much lower than in cell wall phytoliths. The silica cell phytoliths in sorghum developed in the space between the protoplast and the cell wall (Kumar et al., 2017a). In cases like this (Figure 1C), we would expect that phytoliths would not only be low in carbohydrates, but also largely devoid of membranes, DNA and other organic compounds and have very low percentage carbon. Alexandre et al. (2015) found carbon and nitrogen spread evenly across short cell phytoliths from wheat, suggesting that there were no membrane remains, but the possibility that amino acids were present was raised (see below).

Therefore we potentially have a situation where there are two distinct classes of phytoliths that are very different in their carbon concentrations. What other evidence is there for this idea? Jones and Beavers (1963) separated phytoliths on the basis of their specific gravity, and found that those with specify gravity less than 2.10 had a carbon content of $1.6 \%$, well above the overall sample $(0.86 \%)$. In another approach, Yin et al. (2014) heated rice straw phytoliths and found that there were two pools of carbon within them. They attributed the carbon released at lower temperatures 
to that in the cell wall phytoliths, and that at higher temperatures was suggested to come from the lumen phytoliths. Yin et al. (2014) estimated the ratio of cell wall to lumen carbon as 12 or 13 to 1 . These two different approaches both confirm that there are two types of phytolith with different carbon concentrations.

Parr and Sullivan (2014) produced the single paper that comes closest to the overall hypothesis that I am setting out here. They compared two methods of preparing phytoliths from sugarcane and sorghum, microwave digestion, and a rapid digestion using $\mathrm{H}_{2} \mathrm{SO}_{4} / \mathrm{H}_{2} \mathrm{O}_{2}$. The microwave digestion method was less damaging for the phytoliths and retained much more carbon. Parr and Sullivan suggested that there were two main types of phytolith, cavate, and solid. Cavate phytoliths were essentially the cell wall phytoliths of the type often seen in the epidermal long cells where the thin walls form a hollow structure. These would be similar to the situation depicted in Figures 1A, 2. Solid phytoliths were silica cells and other lumen types (Figures 1C,D). The amount of carbon found using microwave digestion was considered by Parr and Sullivan to give an accurate total value for carbon in their preparations, what they termed PhytOC $\mathrm{C}_{\text {Tot }}$ (Table 4). They thought that the rapid digestion procedure removed all of the carbon from the cavate (cell wall) phytoliths, but left it in the solid (lumen) types. This was termed matrix carbon, and hence PhytOC $\mathrm{Cat}_{\text {at }}$ It is then a simple matter to deduct these matrix values from the total to give the cavate (cell wall) percentages $\left(\mathrm{PhytOC}_{\mathrm{Cav}}\right)$. Neither value comes close to the $24.65 \%$ calculated for the Phalaris macrohair (above). This could either suggest that percentage carbon in cell walls varies considerably depending on the source, or that even the microwave digestion technique employed by Parr and Sullivan is over-extracting some carbon.

As an aside, I am not that keen on "cavate" and "solid" as descriptive terms, as many of the cell wall types mentioned in Tables 2, 3 above are solid. But as we have seen, even my preferred terminology of "lumen" and "cell wall" has some problems. It may be that we will need to classify phytoliths according to whether or not they are formed on a carbohydrate matrix.

At this point, I would like to introduce three concepts,

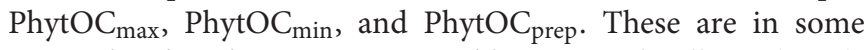
ways related to the terms suggested by Parr and Sullivan (2014). I hope that they will prove helpful in throwing some light on the problems we have encountered with interpreting carbon sequestration in phytoliths. Firstly, $\mathrm{PhytOC}_{\max }$ is the maximum amount of carbon occluded within a phytolith as it drops from a plant into the soil. This will be the amount in native phytoliths before they begin to degrade in the soil or before any attempt at preparation in a laboratory. In practice this is usually very difficult to determine. When phytoliths drop into the soil they are generally surrounded by non-silicified organic material. The

TABLE 4 | Partitioning of carbon in sugarcane and sorghum samples (Parr and Sullivan, 2014).

\begin{tabular}{lrcc}
\hline Species & PhytOC $_{\text {Tot }}$ & PhytOC $_{\text {Mat }}$ & PhytOC $_{\text {Cav }}$ \\
\hline Sugarcane & $10.27 \%$ & $0.15 \%$ & $10.12 \%$ \\
Sorghum & $3.88 \%$ & $0.51 \%$ & $3.37 \%$
\end{tabular}

aim of the preparatory techniques (dry ashing, wet ashing, and microwave digestion) is to remove all of the extraneous organic material without touching that which is bound within the phytolith structure. But it is only in very rare cases such as the Phalaris macrohairs described above (Perry et al., 1987) that we can be sure that we have accurately determined PhytOC $\mathrm{C}_{\max }$. So PhytOC $\max$ is an important, but largely theoretical, concept. Secondly, PhytOC $C_{\text {min }}$ is the amount of carbon remaining in a phytolith after all of the easily available carbon has been removed. Of course, this value is very likely going to differ for different types of phytoliths. We might expect that most of the carbon in cell wall phytoliths will be easier to remove, and maybe that in lumen phytoliths will be less labile. In the soil it may take a long time to reach $\mathrm{PhytOC}_{\min }$ (see below for a discussion), but laboratory preparatory techniques may well approach this value very rapidly. A key question is how many of the measurements in Table $\mathbf{1}$ represent $\mathrm{PhytOC}_{\min }$ and how many are closer to $\mathrm{PhytOC}_{\max }$ ?

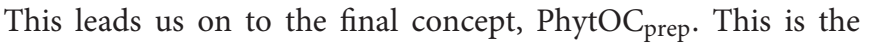
amount of carbon left within a phytolith after it has been subjected to a suitable preparatory technique in the laboratory (the equivalent of PhytOC $\mathrm{C}_{\text {Tot }}$ in Parr and Sullivan's terminology when using microwave digestion). Of course, $\mathrm{PhytOC}_{\text {prep }}$ must lie between $\mathrm{PhytOC}_{\max }$ and $\mathrm{PhytOC}_{\min }$, but exactly where is difficult to be certain, and will depend on the technique used. An important question is whether the $\mathrm{PhytOC}_{\text {prep value of } 3 \%}$

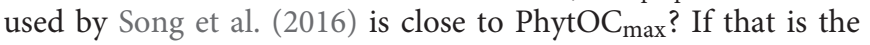

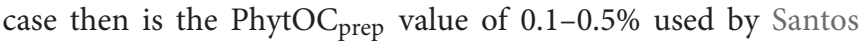
and Alexandre (2017) close to PhytOC $_{\min }$ ? So are both Song et al. (2016) and Santos and Alexandre (2017) "correct," but the PhytOC values they give just represent what is present at different times in phytolith degradation and dissolution? We will have more to say on this point below.

Next we need to investigate mixtures of different types of phytoliths. As, we saw above there are some cases where we are fairly sure that nearly all of the phytoliths in an organ are cell wall types (e.g., the wheat root, and the Phalaris lemma), but in many cases, particularly in the grasses, there will be a mixture of both cell wall and lumen types. The evidence presented here and in my previous publications (Hodson, 2016, 2018) strongly suggests that the two types have very different chemistries, and that cell wall types have much higher carbon concentrations. So, when we have two phytolith types with different PhytOC, how do we calculate the overall PhytOC for the material? To do this, we need to have some estimates of PhytOC for both lumen and cell wall types, and some idea of the relative amounts of the two types of phytolith in a particular sample. Once, we have those estimates we can use the following equation:

$$
(\mathrm{a} \times \mathrm{y} / 100)+(\mathrm{b} \times \mathrm{z} / 100)=\text { Total Percentage PhytOC }
$$

Where:

$\mathrm{a}=$ Percentage PhytOC in lumen phytoliths;

$\mathrm{b}=$ Percentage PhytOC in cell wall phytoliths;

$y=$ The percentage of lumen phytoliths in a sample (out of 100);

$z=$ The percentage of cell wall phytoliths in a sample (out of 100)

(note this formula is constrained by the fact that $\mathrm{y}+\mathrm{z}$ must equal 100). 
We can then investigate a variety of potential scenarios:

(1) Let us assume that PhytOC for the cell wall phytoliths is 24.65\%, as in the Phalaris macrohairs (above), and that lumen PhytOC is $0.33 \%$. The latter is the mean of the two values given by Parr and Sullivan (2014) for lumen (solid) phytoliths, and is not very different to the $0.3 \%$ used by Reyerson et al. (2016) in their calculations on global carbon sequestration.

(2) Let us use the estimates provided by Parr and Sullivan (2014) for sugarcane PhytOC: cell wall, 10.12\%; lumen, $0.15 \%$ (Table 4).

(3) Similarly, the Parr and Sullivan (2014) estimates for sorghum PhytOC: cell wall, 3.37\%; lumen 0.51\%.

Figure 3 shows the effects of varying the ratio of cell wall to lumen phytoliths, moving from a situation where none of the phytoliths are cell wall types to where there are $100 \%$ in a sample. As would be expected, for all three scenarios, a higher percentage of cell wall types leads to a higher total PhytOC. In general Scenario 1 gives higher total PhytOC values under almost all conditions. It is interesting to calculate the percentage of cell wall phytoliths that would be required to reach the $3 \%$ total PhytOC figure that is given by Song et al. (2016) and that is used in many of the other papers from their group. For Scenario 1 only $11 \%$ of cell wall types would be needed, for Scenario 2 (sugarcane) the figure is $29 \%$, and for Scenario 3 (sorghum) it is $88 \%$. Clearly there is very big variation in these figures, but at least in some scenarios a relatively small percentage of cell wall phytoliths would be needed to bring us close to the $3 \%$ figure that Song et al. (2016) preferred.

As far as I am aware nobody has attempted to quantify the relative volumes of cell wall and lumen phytoliths in organs like the grass leaf, and this is an important topic for future research.

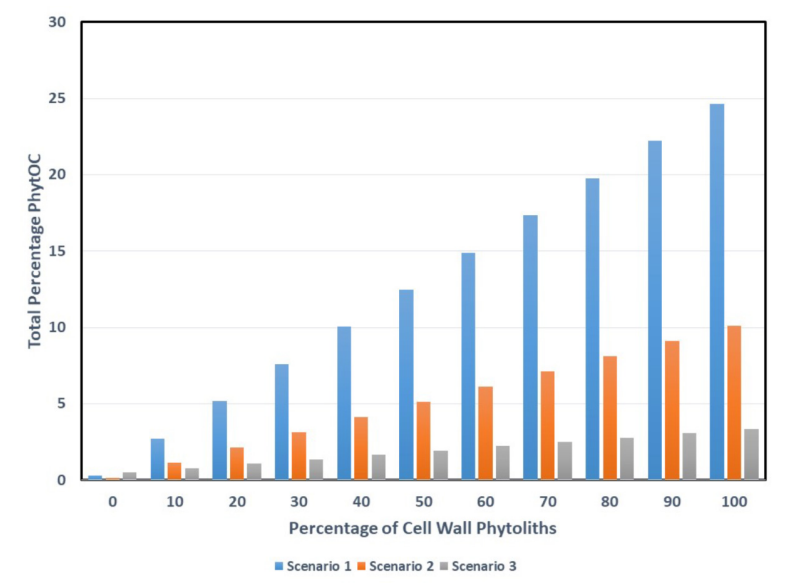

FIGURE 3 | The effects of mixing different amounts of cell wall and lumen phytoliths on total PhytOC. Potential scenarios: (1) PhytOC for the cell wall phytoliths is $24.65 \%$ and PhytOC for lumen phytoliths is $0.33 \%$. (2) PhytOC for the cell wall phytoliths is $10.12 \%$ and PhytOC for lumen phytoliths is $0.15 \%$. (3) PhytOC for the cell wall phytoliths is $3.37 \%$ and PhytOC for lumen phytoliths is $0.51 \%$.
Another key subject arising from this work concerns differences in carbon allocation between species and cultivars. As we saw above, Parr, Sullivan and their team found major differences between PhytOC in phytoliths from different bamboo species, and sugarcane, wheat, and rice cultivars. It has been suggested that it might be possible to breed plants for high PhytOC. But at the cellular level what are we breeding for? Is it simply a change in the ratio of cell wall to lumen phytoliths? Or is it more complex than that?

\section{SOME THOUGHTS ON CARBON AND NITROGEN IN PHYTOLITHS}

There have been few measurements of nitrogen in phytoliths to date. The presence of nitrogen would indicate that proteins, amino acids, and possibly nucleic acids had been incorporated into the phytoliths. Most proteins contain about 53\% carbon and about $16.3 \%$ nitrogen so their $\mathrm{C} / \mathrm{N}$ ratio will be about 3.25 . Values higher than that would suggest that carbohydrates and/or lipids were a significant part of the carbon present in the phytoliths. Table 5 shows the data that I have been able to locate concerning nitrogen concentrations in phytoliths.

Jones and Beavers (1963) were the first to measure nitrogen in phytoliths at $0.01 \%$, which would give a $\mathrm{C} / \mathrm{N}$ ratio of 86 . The accuracy of this $\mathrm{C} / \mathrm{N}$ ratio is probably somewhat questionable given the very low nitrogen concentration, and the age of the work. I was able to calculate the percentage nitrogen in the Phalaris macrohairs studied by Perry et al. (1987). They estimated that percentage protein in the hairs was less than $5 \%$ and so the maximum percentage nitrogen will be $0.82 \%$ at $\mathrm{PhytOC}_{\max }$ in native hairs before treatment. Using the previously calculated value for percentage carbon of $24.65 \%$ we can determine that the $\mathrm{C} / \mathrm{N}$ ratio of Phalaris macrohairs is a minimum of 30 . Hodson et al. (2008) measured nitrogen in phytoliths extracted from various wheat organs using dry ashing followed by boiling in hydrogen peroxide. They found low, but detectable, amounts of $0.01-0.06 \%$ nitrogen. The calculated $\mathrm{C} / \mathrm{N}$ ratios varied from 7 to 43 , depending on the organ, with the bulk sample containing all organs giving a value of 41 . Fragmented glycoproteins were found in wheat leaf phytoliths by Elbaum et al. (2009), confirming the presence of nitrogenous compounds, although they did not quantify the amounts. The leaf short cell phytoliths of Triticum durum were analyzed using nanoSIMS by Alexandre et al. (2015). They were not able to quantify carbon and nitrogen concentrations, but their $\mathrm{C} / \mathrm{N}$ ratio was 3.7. In the following year, Alexandre et al. (2016) wet ashed the leaves of Festuca arundinacea and found that the phytoliths had a $\mathrm{C} / \mathrm{N}$ ratio of 5.1.

How do we interpret the above data? Firstly, it is striking that the values for $\mathrm{C} / \mathrm{N}$ ratio in Table 5 fall into two groups with the rachis of wheat and the analyses conducted by Alexandre et al. $(2015,2016)$ giving markedly lower values than the rest. The value for native Phalaris macrohairs calculated from Perry et al. (1987) gives an approximate baseline for cell wall phytoliths with a minimum $\mathrm{C} / \mathrm{N}$ ratio of 30 . It seems that the $\mathrm{C} / \mathrm{N}$ signature for cell wall phytoliths dominates the wheat samples analyzed by Hodson et al. (2008) even after they have undergone dry 
TABLE 5 | Phytolith carbon and nitrogen analyses.

\begin{tabular}{|c|c|c|c|c|c|c|}
\hline Species & Plant organ(s) or cell type & $\% \mathbf{C}$ & $\% \mathbf{N}$ & $\mathrm{C} / \mathrm{N}$ ratio & Technique & Authors \\
\hline Various & Phytoliths extracted from soil & 0.86 & 0.01 & 86 & Not given & Jones and Beavers, 1963 \\
\hline Phalaris canariensis & Lemma macrohairs & 24.65 & $0.82 \max$ & $30 \mathrm{~min}$ & Analysis of native hairs & Perry et al., 1987 \\
\hline \multirow[t]{6}{*}{ Wheat (Triticum aestivum) } & Culm & 1.25 & 0.05 & 25 & $\begin{array}{l}\text { Dry ashing followed by boiling in } \\
\text { hydrogen peroxide }\end{array}$ & Hodson et al., 2008 \\
\hline & Leaf sheath & 1.22 & 0.03 & 41 & & \\
\hline & Leaf blade & 1.72 & 0.04 & 43 & & \\
\hline & Rachis & 0.07 & 0.01 & 7 & & \\
\hline & Inflorescence & 1.67 & 0.06 & 29 & & \\
\hline & Bulk & 1.65 & 0.04 & 41 & & \\
\hline Triticum durum & Leaves- only silica cells analyzed & nd & nd & 3.7 & Wet ashing for NanoSIMS analysis & Alexandre et al., 2015 \\
\hline Festuca arundinacea & Leaves & 0.51 & 0.10 & 5.1 & Wet ashing & Alexandre et al., 2016 \\
\hline
\end{tabular}

ashing and boiling in hydrogen peroxide. Alexandre et al. (2015) were quite correct to point out that their nanoSIMS analysis for leaf short cells strongly suggests the presence of amino acids with a $\mathrm{C} / \mathrm{N}$ ratio of 3.7 in these lumen phytoliths. This forms a baseline for lumen phytoliths. When Alexandre et al. (2016) wet ashed $F$. arundinacea leaves, the phytoliths within them had a slightly higher $\mathrm{C} / \mathrm{N}$ ratio of 5.1, again suggesting dominance of amino acids and proteins. It seems very likely that the extraction procedure used by Alexandre et al. (2016) was stronger than that used by Hodson et al. (2008), and that they removed most of the carbon from within the cell wall phytoliths, leaving that in the lumen phytoliths largely intact. This thinking is along similar lines to that of Parr and Sullivan (2014), where cell wall (cavate) phytoliths were considered to be more susceptible to extraction than lumen (solid) phytoliths. The wheat rachis sample had very low carbon and nitrogen in its phytoliths, and I suspect that this relatively lightly silicified organ was also over-extracted. More work is needed employing $\mathrm{C} / \mathrm{N}$ ratios for phytolith analyses to confirm these ideas, but this ratio certainly seems to have potential for assessing the relative contributions of carbohydrates and amino acids within a processed sample.

\section{THE LOSS OF CARBON FROM PHYTOLITHS IN THE SOIL AND SEDIMENTS}

The evidence I have presented so far in this paper very strongly suggests that lumen phytoliths generally have low PhytOC. Even Parr and Sullivan (2014), the originators of the carbon sequestration in phytoliths idea, are proposing values as low as $0.15-0.51 \%$ (Table 4). As, we saw above, Reyerson et al. (2016) calculated global carbon sequestration using a PhytOC of $0.3 \%$, assuming that this applied to all phytoliths, and concluded that sequestration would be insignificant. So if lumen phytoliths are not that important for carbon sequestration the whole hypothesis hangs on the cell wall phytoliths. However, the general assumption is that cell wall phytoliths are less likely to remain in soil as they are more easily broken down (Song et al., 2017). But is this really the case?
Strömberg et al. (2018) have produced a very detailed assessment of what happens to phytoliths when they enter the soil, and we will not go back over all of this material, but mostly concentrate on any differences between cell wall and lumen phytoliths. It is clear that, in many soil environments, a considerable amount of siliceous plant material, including phytoliths, breaks down fairly quickly. Indeed, phytoliths are often an important source of dissolved Si in soils as they are much more soluble than quartz, aluminosilicates, and other soil minerals. Working on a temperate coniferous forest, Gérard et al. (2008) showed that $60 \%$ of the biogeochemical cycle was controlled by biological processes, namely Si uptake by plants and dissolution of phytoliths. There is a large labile pool of phytogenic silica in soils (Strömberg et al., 2018), with values for this pool ranging from $69 \%$ in short grass prairie to $92 \%$ in tropical forest.

Puppe et al. (2017) conducted a detailed analysis of the contribution of biogenic silica to the soil soluble silicon pool at Chicken Creek in Brandenburg, Germany. They considered diatoms and sponge spicules in addition to phytoliths, but it was the latter that were by far the most important in contributing to soluble silicon concentrations in the soil. However, they discovered that small, delicate, phytolith fragments which were not usually quantified using standard extraction processes made up $84 \%$ of the phytogenic material and those larger than $5 \mu \mathrm{m}$ represented only $16 \%$. The authors stressed the importance of this large pool of small delicate material in contributing to soluble silicon in the soil. The micrographs of the fragile phytoliths they showed (their Figure 7) were not that dissimilar to my Figure 2 with thin cell wall silicification. Clearly these structures would be highly susceptible to dissolution. Presumably the larger phytoliths that represented $16 \%$ of the phytogenic material would remain in the soil for much longer periods.

At the global scale, the phytolith stability factor was one of the disagreements between Song et al. (2016) and Santos and Alexandre (2017). The former suggested a stability factor of 0.8 to 1.0 as phytoliths in most systems are stable for 500 to 3000 years. However, Santos and Alexandre (2017) suggested a stability factor of $20 \%$, which combined with their much lower value of PhytOC $(0.3 \%)$, led them to suggest that carbon sequestration in phytoliths on a global scale was insignificant. As we saw above, it 
seems very likely that the value of $0.3 \%$ PhytOC used by Santos and Alexandre is an underestimate due to over-extraction, and that particularly applies to cell wall phytoliths. It is difficult to speculate on the influence of cell wall phytoliths on the stability factor as we lack even basic data.

Next we will investigate the dissolution of lumen and cell wall phytoliths. I recently reviewed this topic (Hodson, 2018), and a number of factors seem to be important. Of the soil chemical factors, high $\mathrm{pH}$ was the most significant, causing increased phytolith dissolution. It is possible that aluminum in phytoliths may decrease their dissolution, but their carbon content hardly seems to have been considered. Cabanes and Shahack-Gross (2015) carried out the most detailed work so far on this topic but, with the exception of the double peaked glume phytoliths from rice husks, most of their work concentrated on lumen types. The key factor in increasing phytolith solubility was geometric surface to bulk ratio. There was no indication that cell wall phytoliths were either more or less soluble.

We should now consider what is known about cell walls that have undergone silicification. The small number of measurements so far available for carbon in cell wall phytoliths shows considerable variability (see above: Perry et al., 1987; Parr and Sullivan, 2014). If the percentage carbon is high then percentage silicon must be low and vice versa. We would not necessarily expect all cells walls to be silicified to the same extent, but this will mean that they will vary in their chemical properties, and potentially in how susceptible they are to breakdown processes in the soil. I previously discussed evidence that suggests that after the organic matter is removed from cell wall phytoliths the remaining silica has a porous structure (Hodson, 2016). Since that publication, Sola-Rabada et al. (2018) have published the first estimate of the size of the pores that I am aware of. In phytoliths isolated from Equisetum myriochaetum using wet ashing the silica had a surface area of $\sim 400 \mathrm{~m}^{2} \cdot \mathrm{g}^{-1}$ and a pore size of $\sim 5 \mathrm{~nm}$. Presumably, in the native state these pores will have been filled by carbohydrates and other organic compounds. Almost certainly pore size will vary, and we might expect more lightly silicified material to have larger pores. But we should remember that these cell wall phytoliths are only porous after most of the organic matter has been removed with drastic treatment. Will cell wall phytoliths necessarily be more susceptible to breakdown in the soil than lumen types just because they have higher organic matter within them? Does being encrusted by silica slow down the microbial degradation of organic matter in phytoliths? Conversely, does being so intimately associated with organic matter impede the dissolution of silica from phytoliths? We do not know the answers to these questions yet.

There is not very much known about how silica and organic matter are associated in the soil. However, the work of Watteau and Villemin (2001) on the breakdown of leaves and roots soils of a beech forest is important in this respect. Using TEM and electron energy loss spectroscopy (EELS) they found silica was deposited in beech leaves in the walls of the epidermal and parenchymatous cells, in the middle lamellae, against the walls in the cells, or in cell intersections. The authors stressed the close relationships between biogenic silica and cellulose, hemicellulose, and pectic substances in these samples. Deposition was in similar locations in the cell walls of beech roots, but also in the root cortical cells closely associated with polyphenolic substances. In the soil the leaf and root tissues were broken down primarily by fungi, but bacteria were also present. The fungi attacked the carbohydrates in the cell walls, leaving the silica largely intact, particularly that in the cell intersections. More recently, Turpault et al. (2018) also investigated silicon cycling in beech forests. Much of the silicon was associated with cell walls in the beech tissues. Turpault et al found that fine beech roots were particularly important in cycling as they had a high Si content and were rapidly broken down and recycled. Very little Si was lost from the system through deposition in perennial tissues or leaching from the soil, and it was an almost closed system. It is clear from both Watteau and Villemin (2001) and Turpault et al. (2018) that cell wall Si deposition is the most important in beech, and in the soils beneath the forests. The papers also give us some insights into breakdown of cell wall phytoliths in soils and how rapid this can be. The beech cell walls investigated appear to be fairly thin and relatively lightly silicified (similar to Figure 1A), and it would be unwise to extrapolate from this situation to others where heavier silicification has occurred.

As I was writing this paper, the Intergovernmental Panel on Climate Change (IPCC) brought out their 2018 report on the feasibility of keeping the global temperature rise under $1.5^{\circ} \mathrm{C}$ above the pre-industrial temperature. The report has a section (4.3.7.3) which considers increasing carbon sequestration in soils as one of the means of tackling the problem (de Coninck et al., 2018). At a local scale the benefits of increasing carbon sequestration in soils are clear, but there is much uncertainty about how much carbon can be sequestered at a global scale and what the costs might be. The section does consider work on the use of biochar to increase sequestration but, rather like work on phytoliths, there is considerable debate about its potential. Not surprisingly, the idea that phytoliths might be involved in carbon sequestration in soils has not yet impinged on the IPCC. We will need much more work and much greater certainty before that might happen.

Before we leave this topic, I have one more question to raise. How long do we need to sequester carbon? There seems to be a general assumption in the phytolith literature that we need to sequester carbon for hundreds or thousands of years, and that sequestration for shorter periods is not worthwhile. Parr and Sullivan (2005) found phytoliths from 8710 BP at Byron Bay in Australia still contained PhytOC, and so sequestration is possible for very long periods of time. However, I would argue that the problems that we are having with climate change are so severe that we need to maximize short term sequestration, and that even locking away carbon in phytoliths for 50 or 100 years might make a valuable contribution. In that time we might hope that the world will make the switch to renewable technologies, and that we might have developed other methods for sequestering carbon. The IPCC have made it very clear how urgent the problem of climate change is, and the short time scales involved to reduce what could be very serious impacts. We need to keep this in mind as we investigate carbon sequestration in phytoliths. 


\section{DO CELL WALL PHYTOLITHS REMAIN IN ARCHEOLOGICAL AND PALAEOECOLOGICAL SAMPLES?}

In the previous section, we investigated what is known about the chemistry of phytolith breakdown and dissolution in the soil and sediments. It is highly unclear whether cell wall phytoliths are degraded faster than lumen phytoliths as there is little data available. Since this is the case, we will now turn to the archeological and palaeoecological literature to investigate whether cell wall phytoliths persist in soils and sediments.

As we have seen earlier it is not always easy to determine whether a phytolith has a carbohydrate matrix, so we will confine this survey mostly to macrohairs, prickle hairs and papillae (Table 6). The double-peaked rice husk phytoliths are also cell wall phytoliths occurring on the outer surface of the rice husk, and they are heavily silicified (Park et al., 2003). An additional category we will add are multi-celled phytoliths, also known as silica skeletons (Rosen and Weiner, 1994). These are groups of phytoliths frequently, but not only (see Figure 2), originating from the husks of cereals. They often contain papillae within their structures, and will inevitably enclose cell walls between the different cells. Included within the silica skeletons are the cut phytoliths which appear in archeological contexts, and are diagnostic for cutting and threshing activities (Cummings, 2007).

Table 6 represents the results of a partial survey of the literature, and there are many other papers that could have been cited. However, it is clear that cell wall phytoliths can be found in samples that are hundreds or thousands of years old. In two cases (Prasad et al., 2005; Wu et al., 2018) they were found associated with dinosaur remains from the Cretaceous. Here, we would expect that the phytoliths discovered will be fossilized and have lost their original organic matter, but it does indicate that they persisted long enough to be preserved in this way. Cell wall types have been found in many different contexts and environments, from extremely arid to temperate, and in many different countries. It would not be wise to attempt any sort of quantification, particularly as we are uncertain how many long cell phytoliths have a carbohydrate matrix (see Figure 1B and discussion above). I have included both archeological and palaeoecological examples in Table 6. It could be argued that archeological contexts do not always replicate conditions from the natural environment. However, it is now recognized that agriculture is having a major impact on the global silicon cycle (Struyf et al., 2010), and so, to some extent, the work on past agricultural activity is an analog for what is happening today. Moreover, much of the work on increasing carbon sequestration in phytoliths in the future concerns agricultural crops (Parr and Sullivan, 2011).

In conclusion, the small survey shown in Table $\mathbf{6}$ has strongly indicated that cell wall phytoliths can persist in soils and sediments for considerable periods of time. It is conceivable that these cell wall phytoliths may have lost much of their organic matter over time, but that their basic structure remains intact. It is, however, more likely that they still contain substantial amounts of carbon hidden deep within the phytolith structure. So we are faced with the possibility that some carbon may be sequestered in cell wall phytoliths for hundreds or thousands of years. But as we argued above, the more important issue is how much carbon is sequestered for short periods of time, maybe 100 years.

\section{A HYPOTHESIS}

Having gathered together data and observations from many different sources I am now able to put forward a hypothesis which attempts to explain the overall picture. First, let us reflect on what happens when phytoliths are prepared for analysis by wet ashing, dry ashing or microwave digestion:

(1) The non-silicified material is rapidly removed to expose the phytoliths. The phytoliths are then at $\mathrm{PhytOC}_{\max }$.

(2) The more porous cell wall phytoliths will be more vulnerable to carbon loss than the lumen phytoliths.

(3) If the extraction procedure is not too severe then carbon will remain in both cell wall and lumen phytoliths. The

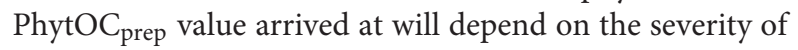
the extraction procedure.

(4) If the process is more severe then all the cell wall phytolith carbon will be lost, but that in the lumen phytoliths will be much less affected. Here, we reach $\mathrm{PhytOC}_{\min }$.

(5) Only if extreme procedures are used will all the carbon be lost from all phytoliths. For example, Yin et al. (2014) showed that at very high temperatures (above $900^{\circ} \mathrm{C}$ ) most carbon is removed from rice and millet phytoliths.

Now let us consider the situation in the soil:

(1) When plant material falls into the soil or becomes incorporated into it, cell wall and lumen phytoliths are all surrounded by non-silicified material.

(2) Depending on the soil conditions the non-silicified plant matter rots fairly quickly to expose the phytoliths within it. The phytoliths are then at $\mathrm{PhytOC}_{\max }$.

(3) The lumen phytoliths contain a small amount of carbon, but are resistant to breakdown in the soil.

(4) The cell wall phytoliths contain a much larger amount of carbon, but are more easily broken down in the soil.

(5) Within a short period of time (a few decades) much of the smaller, lightly silicified cell wall and intercellular silica deposition breaks down. The silica dissolves and the organic material contained within it undergoes decomposition and is released back to the atmosphere as carbon dioxide.

(6) The remaining cell wall and lumen phytoliths then dissolve and break down more slowly over centuries or millennia. It may be a very long time before they reach $\mathrm{PhytOC}_{\min }$.

(7) Depending on the plant species and organs that originally contributed the phytoliths either the lumen or cell wall deposits are the more important in sequestering carbon in the soil. This part of the hypothesis requires further exploration, and this is carried out below.

From the work of Watteau and Villemin (2001) and Turpault et al. (2018) it is evident that cell wall phytoliths are the most important in the soils of beech forests. I am not aware of similar work for the soils of coniferous forests. However, my 
TABLE 6 | Cell wall phytoliths in archeological and palaeoecological samples.

\begin{tabular}{|c|c|c|c|}
\hline Location & Date or historical period & Cell wall phytoliths present & Authors \\
\hline Maidanetske central Ukraine & ca. 3900-3650 BCE, Chalcolithic & Silica skeletons, hairs, papillae & Dal Corso et al., 2018 \\
\hline Taraschina, Romania & Chalcolithic, 4800 to 4300 cal. BC & Silica skeletons, hairs, papillae & Danu et al., 2018 \\
\hline $\begin{array}{l}\text { Court of Hoogstraeten, Brussels, } \\
\text { Belgium }\end{array}$ & 10th to 17th century AD & Silica skeletons & Devos et al., 2013 \\
\hline $\begin{array}{l}\text { Lake End Road West, } \\
\text { Buckinghamshire, United Kingdom }\end{array}$ & Anglo-Saxon to post-medieval & Silica skeletons, epicarp hairs, papillae & Hodson, 2002 \\
\hline Pacific Northwest, United States & Modern & Prickles, hairs & Blinnikov, 2005 \\
\hline $\begin{array}{l}\text { Bear Creek, Cedar County, Missouri, } \\
\text { United States }\end{array}$ & Holocene (back to 5000 BP) & Trichomes & Donohue and Dinan, 1993 \\
\hline Nebraska and Kansas, United States & Neogene, 18 to $2 \mathrm{Ma}$ & Hairs, papillae & Strömberg and Mclnerney, 2011 \\
\hline Monte Castelo, Amazonia, Brazil & $625-5310 \mathrm{cal}$ year BP & Double-peaked glume phytoliths (rice) & Hilbert et al., 2017 \\
\hline Beth Shemesh, Israel & Iron age & Multi-celled & Asscher et al., 2017 \\
\hline Various sites in Israel & Neolithic & Multi-celled, papillae, hairs & Rosen, 1993 \\
\hline Northern Negev, Israel & 6000BP, chalcolithic & Multi-celled (wheat) & Rosen and Weiner, 1994 \\
\hline Kush, United Arab Emirates & 4th to 13th century AD & Silica skeletons, hairs, papillae & Ishida et al., 2003 \\
\hline Rub' al-Khali desert, Arabian Peninsula & 8500 cal. yr BP to about 3000 cal. yr BP & Hairs & Parker et al., 2004 \\
\hline Central North China & Mid-Late Neolithic, c. 5500 to 2100 cal. yr BP & Double-peaked (rice), silica skeletons, hairs & Zhang et al., 2010 \\
\hline Northeast China & Modern & Hairs & Gao et al., 2018 \\
\hline Northwest China & Early cretaceous (113-101 Ma) & Silica skeletons & Wu et al., 2018 \\
\hline Balathal, South Rajastan, India & Late chalcolithic - early historical & Silica skeletons, trichomes, hairs & Kajale and Eksambekar, 2007 \\
\hline Pisdura, India & Late cretaceous & Silica skeletons, papillae & Prasad et al., 2005 \\
\hline Various & Various & Cut silica skeletons & Cummings, 2007 \\
\hline
\end{tabular}

previous work on conifer needles has strongly indicated that cell wall deposition is important in this group. For example, Hodson and Sangster (1998) found that silica deposition was almost entirely confined to the hypodermal and endodermal walls of white spruce needles. Presumably this would be reflected in the phytoliths to be found in the soils of conifer forests. In grasslands it is probable that lumen phytoliths (particularly short cells) will dominate in most phytolith assemblages isolated from soils. In these cases we may need to balance a very large number of lumen phytoliths that contain small amounts of carbon against a smaller number of cell wall phytoliths that contain much more carbon. It may be that a modified form of Equation 1 could be used in these circumstances to determine the overall PhytOC percentage. Very recently, Zhang et al. (2019) showed the importance of bamboo litter layers in carbon sequestration, and demonstrated the considerable potential that exists to increase carbon sequestration in the future. But what types of phytoliths might we expect to dominate the litter layers? Firstly, it is clear that bamboo leaves contain much higher silicon concentrations than the other organs (Collin et al., 2012), and these will undoubtedly be the major contributor to phytoliths in the litter. Lux et al. (2003) investigated silicification of bamboo (Phyllostachys heterocycla Mitf.) leaves and found the highest Si concentrations were in the epidermal cell walls and short cells. This suggests that bamboo litter should contain both cell wall and lumen phytoliths. Which will be dominant in the litter is uncertain. We have seen that bamboo species differ in the amount of PhytOC within their phytoliths (Parr et al., 2010), and we might also expect that the litter will vary in the relative amounts of cell wall and lumen phytoliths, depending on the species involved.
I am not clear whether lumen phytoliths or cell wall phytoliths will be the more significant in sequestering carbon at a global scale. At the moment we have not got enough data even to make an informed guess on the relative importance of the two phytolith types in carbon sequestration at this scale.

\section{PRIORITIES FOR FUTURE RESEARCH}

A number of important research topics have arisen from the present study:

(1) We have seen that there is some uncertainty about which phytoliths are deposited on a carbohydrate matrix. This is particularly the case for long cells. Hodson et al. (1984) showed that silica was deposited onto thickened secondary cell walls in the long cells of the outer epidermis of the lemma of $P$. canariensis (similar to Figure 1B). I am not aware of any other examples of this phenomenon, but surely it cannot be the only case? Long cells are important sites of silica deposition, and if it were discovered that the lumen of many had a carbohydrate matrix they could be very significant repositories for carbon sequestration. The work would require plant scientists (probably) to use TEM and $\mathrm{x}$-ray microanalysis following a developmental sequence as the cells silicified.

(2) What is the ratio of cell wall to lumen phytoliths in organs where they are both present? If we knew this we would have data that could be used in Equation 1. We would then be able to assess the relative importance of cell wall and lumen carbon sequestration. This work probably requires microscopy and image analysis. 
(3) We know from the work of Parr, Sullivan and others that there are differences between cultivars in PhytOC. But what is the difference at the cellular level? There have also been suggestions that it might be possible to breed for high carbon sequestration in phytoliths. Are we breeding for a change in the ratio of cell wall and lumen phytoliths? Again this work will require microscopists and image analysis.

(4) It appears that the $\mathrm{C} / \mathrm{N}$ ratio of phytoliths might have some promise in indicating whether preparations are dominated by amino acids or carbohydrates and whether samples are over-extracted, but this work needs to be expanded. For instance, it would be of great interest to repeat the work of Parr and Sullivan (2014) using both drastic wet ashing and gentler microwave digestion preparative procedures, and then analyze for both $\mathrm{C}$ and $\mathrm{N}$. If my thinking above is correct I would predict that the wet ashing preparation will have a lower $\mathrm{C} / \mathrm{N}$ ratio than that obtained through microwave digestion.

(5) We need to determine whether the breakdown and dissolution of cell wall phytoliths is faster than that of lumen phytoliths in experimental situations. Here, we could repeat the work of Cabanes and Shahack-Gross (2015) on phytolith dissolution, but specifically comparing cell wall and lumen phytoliths.

(6) In the soil, we have a very incomplete picture of the processes involved in phytolith dissolution, and even more so for cell wall phytoliths. More work of the type described by Watteau and Villemin (2001) on beech forest soils is needed.

(7) Parr and Sullivan (2005) found carbon in phytoliths from 8710 BP. We have seen that cell wall phytoliths can remain in archeological and palaeoecological samples for hundreds or thousands of years, but does carbon remain within them? If so it would suggest the potential for high carbon sequestration, but if not then cell wall phytoliths must be strong even once carbohydrates have been removed.

\section{MY CONCLUSION AND PERSPECTIVE}

I said at the beginning of this paper that I would not take sides in what has become an acrimonious debate over carbon sequestration in phytoliths. However, having carried out a detailed analysis and weighed up all the evidence I conclude that the hypothesis that carbon sequestration in phytoliths is important on a global scale is probably correct, or at least cannot yet be discarded. I think it is likely that all workers in this area (and I include myself) have over-extracted phytoliths, and that we have not given an accurate representation of $\mathrm{PhytOC}_{\max }$. It is probable that Alexandre, Santos and their co-workers have over-extracted to the point where their preparations are

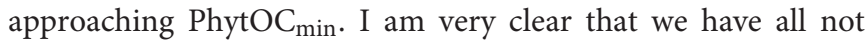
taken enough account of heterogeneity in phytolith chemistry. It seems very likely that cell wall phytoliths are important in carbon sequestration, and it may even prove to be the case that they are more significant than the lumen types. In this paper I have considered lumen and cell wall phytoliths, but it is quite possible that this is an oversimplification and that there are more than two types or some gradation between the two (e.g., the situation in Figure 1E). There is no doubt that what I have presented here makes the whole topic of carbon sequestration in phytoliths even more complex than it was, but if we are to move this field forward then these complexities need to be accounted for.

I have worked on phytoliths for nearly 40 years. Much of my work has been what some people call "blue skies" research. That is it had no obvious immediate practical application. So, I have been quite surprised that some of my publications on microanalysis and phytolith development from the 1980s now have a new relevance in 2019 when we consider carbon sequestration and PhytOC. I suspect that quite a few of the authors cited in this paper will be equally surprised. I do worry that financial pressures mean that we are losing the possibility to research topics just because they are interesting.

Many scientists from very diverse disciplines have contributed to the picture I have painted in this paper. However, if we look specifically at the question of carbon sequestration in phytoliths a few people stand out. Foremost among these must be Jeffrey Parr and Leigh Sullivan who first had the idea that phytoliths might sequester substantial amounts of carbon. All of the data was already there for everyone to see, but they had the idea, and the sudden spark of brilliance that really created a whole new field of phytolith research. They then carried out a considerable amount of work to test their hypothesis, and particularly to look at variation in carbon sequestration in phytoliths from related species and cultivars. If Parr and Sullivan were the originators of the idea, then Zhaoliang Song and his team in China were those who tested it out in a whole string of investigations. We should also be grateful to Ann Alexandre, Guaciara Santos and their co-workers who "shook the tree" and made us all wonder if sequestration of carbon in phytoliths was an important phenomenon. I disagree with their overall conclusion on the importance of carbon sequestration in phytoliths, but they are very good scientists and have done some excellent work in this area. It was through their work that I hit on the concept of PhytOC $_{\text {min }}$, which I have described above. They also provided some useful data on nitrogen in phytoliths which was crucial in my thinking about $\mathrm{C} / \mathrm{N}$ ratios. Finally, I must mention Carole Perry, whose work on the chemistry of phytoliths has been seminal. I used some of her early research to develop the idea of PhytOC $C_{\max }$, and in many ways her analysis of the Phalaris macrohair (Perry et al., 1987) was the key to unlocking this puzzle. I am sure that Carole would never have guessed back in the 1980s that her work would be used in this way. For me this is a fascinating story that has developed over more than 30 years. It is notable that much of the research I have based my ideas on was originally "blue skies," but now it makes a significant contribution to a very important topic.

As I write in 2019, the evidence for the effects of humaninduced climate change is all too obvious from around the world. The IPCC report (2018) that I mentioned above laid out what we need to do to avoid a very perilous future. For the last 15 years I have spent much time speaking and writing about climate change for general, non-scientific audiences (Hodson and Hodson, 2011, 2013 , 2015). Every new talk I prepare or article I write about 
climate change makes me aware of just how serious and urgent this issue is. Now I am approaching my 40th anniversary of working on phytoliths, and we can see that they might have a potential role in carbon sequestration in soils. I am not convinced that phytoliths will be a "silver bullet" for climate change, but the work described above suggests that they may have a role to play. We now really need a concerted and determined effort from the whole phytolith community to test out some of the ideas laid out above. There are key topics for scientists from many different disciplines to work on, from those investigating phytolith chemistry and formation at a molecular level right up to those studying biogeochemical cycles. It is extremely important that we maintain very good communications between all these scientists, and not end up in disciplinary boxes. There is a lot to recommend the phytolith superdiscipline idea of Katz (2018), where boundaries between disciplines are dissolved.

There has been considerable tension within the phytolith community over carbon sequestration in the last few years, and academic disagreements have turned to friction and friction to heat. I sincerely hope that all of the scientists working on carbon sequestration in phytoliths will one day be reconciled (and reconciliation is even more needed where dating of phytoliths is concerned). This issue is too important for personal rivalries to get in the way. I would appeal for all involved to work together toward a common goal. That goal is working out how important PhytOC is, and if it is important then finding ways of using

\section{REFERENCES}

Alexandre, A., Balesdent, J., Cazevieille, P., Chevassus-Rosset, C., Signoret, P., et al. (2016). Direct uptake of organically derived carbon by grass roots and allocation in leaves and phytoliths: ${ }^{13} \mathrm{C}$ labeling evidence. Biogeosciences 13, 1693-1703. doi: 10.5194/bg-13-1693-2016

Alexandre, A., Basile-Doelsch, I., Delhaye, T., Borshneck, D., Mazur, J. C., Reyerson, P., and Santos, G. M. (2015). New highlights of phytolith structure and occluded carbon location: 3-D X-ray microscopy and NanoSIMS results. Biogeosciences 12, 863-873. doi: 10.5194/bg-12-863-2015

Alexandre, A., Bouvet, M., and Abbadie, L. (2011). The role of savannas in the terrestrial Si cycle: a case-study from Lamto, Ivory Coast. Glob. Planet Change 78, 162-169. doi: 10.1016/j.gloplacha.2011.06.007

Asscher, Y., Weiner, S., and Boaretto, E. (2017). A new method for extracting the insoluble occluded carbon in archaeological and modern phytoliths: detection of ${ }^{14} \mathrm{C}$ depleted carbon fraction and implications for radiocarbon dating. J. Archaeol. Sci. 78, 57-65. doi: 10.1016/j.jas.2016.11.005

Blinnikov, M. S. (2005). Phytoliths in plants and soils of the interior Pacific Northwest, USA. Rev. Palaeobot. Palynol. 135, 71-98. doi: 10.1016/j.revpalbo. 2005.02.006

Cabanes, D., and Shahack-Gross, R. (2015). Understanding fossil phytolith preservation: the role of partial dissolution in paleoecology and archaeology. PLoS One 10:e0125532. doi: 10.1371/journal.pone.012 5532

Collin, B., Doelsch, E., Keller, C., Panfili, F., and Meunier, J.-D. (2012). Distribution and variability of silicon, copper and zinc in different bamboo species. Plant Soil 351, 377-387. doi: 10.1007/s11104-011-0974-9

Corbineau, R., Reyerson, P. R., Alexandre, A., and Santos, G. M. (2013). Towards producing pure phytolith concentrates from plants that are suitable for carbon isotopic analysis. Rev. Palaeobot. Palynol. 197, 179-185. doi: 10.1016/j.revpalbo. 2013.06.001.

Coskun, D., Deshmukh, R., Sonah, H., Menzies, J. G., Reynolds, O., Ma, J. F, et al. (2018). The controversies of silicon's role in plant biology. New Phytol. 221, 67-85. doi: 10.1111/nph.15343 the knowledge gained as quickly as possible. Put aside previous arguments and get on with the job. I will gladly work with anyone who wants advice or help, and I will not be upset if some of the thinking above is incorrect. I have put forward a hypothesis which seems to explain the available data, but it is a hypothesis and it needs testing. If, in 10 years' time, someone writes, "Hodson got it totally wrong, but he gave me some ideas, and now we have it right," then I will be very happy.

\section{AUTHOR CONTRIBUTIONS}

The author confirms being the sole contributor of this work and has approved it for publication.

\section{ACKNOWLEDGMENTS}

I would like to dedicate this paper to the memory of my friend and colleague, Allan Sangster who died on September 6, 2018, aged 91. I published more papers with Allan than with anyone else, and it is fair to say that without him the present paper would never have happened. I am particularly grateful to my wife, Margot, for allowing me to bounce ideas off her for this paper. Even more grateful as sometimes our conversations were in the early hours of the morning! With all my love Martin.

Cummings, L. S. (2007) "Phytoliths as artifacts: evidence of threshing on silica bodies," In Plants, People and Places: Recent Studies in Phytolithic Analysis, eds M. Madella, and D. Zurro (Oxford: Oxbow Books), 149-154.

Currie, H. A., and Perry, C. C. (2007). Silica in plants: biological, biochemical and chemical studies. Ann. Bot. 100, 1383-1389. doi: 10.1093/aob/mcm247

Dal Corso, M., Out, W. A., Ohlrau, R., Hofmann, R., Dreibrodt, S., Videiko, M., et al. (2018). Where are the cereals? Contribution of phytolith analysis to the study of subsistence economy at the Trypillia site Maidanetske (ca. 3900-3650 BCE), central Ukraine. J. Arid. Env. 157, 137-148. doi: 10.1016/j.jaridenv.2018. 06.009

Danu, M., Messager, E., Carozza, J.-M., Carozza, L., Bouby, L., Philibert, S., et al. (2018). Phytolith evidence of cereal processing in the Danube Delta during the Chalcolithic period. Quat. Int. 504, 128-138. doi: 10.1016/j.quaint.2018.03.033

Dayanandan, P., and Kaufman, P. B. (1976). Trichomes of Cannabis sativa L. (Cannabaceae). Am. J. Bot. 63, 578-591. doi: 10.1002/j.1537-2197.1976. tb11846.x

de Coninck, H., Revi, A., Babiker, M., Bertoldi, P., Buckeridge, M., Cartwright, A., et al., (2018) "Strengthening and implementing the global response," In Global Warming of $1.5^{\circ} \mathrm{C}$. An IPCC Special Report on the Impacts of Global Warming of $1.5^{\circ} \mathrm{C}$ Above Pre-Industrial Levels and Related Global Greenhouse gas Emission Pathways, in the Context of Strengthening the Global Response to the Threat of Climate Change, sustainable Development, and Efforts to Eradicate Poverty, ed. V. Masson Delmotte et al. (Geneva: IPCC), 313-443.

Devos, Y., Nicosia, C., Vrydaghs, L., and Modrie, S. (2013). Studying urban stratigraphy: dark earth and a microstratified sequence on the site of the Court of Hoogstraeten (Brussels, Belgium). Integrating archaeopedology and phytolith analysis. Quat. Int. 315, 147-166. doi: 10.1016/j.quaint.2013.07.024

Donohue, J. A., and Dinan, E. H. (1993) “A Geoarchaeological Analysis of Phytolith Data from the Bear Creek Sire, Cedar County, Missouri," In Current Research in Phytolith Analysis: Applications in Archaeology and Paleoecology, MASCA Research Papers in Science and Archaeology, eds D. M. Pearsall and D. R. Piperno (Pennsylvania, PA: University of Pennsylvania Museum), 83-94.

Elbaum, R., Melamed-Bessudo, C., Tuross, N., Levy, A. A., Weiner, S. (2009). New methods to isolate organic materials from silicified phytoliths reveal fragmented 
glycoproteins but no DNA. Quat. Int. 193, 11-19. doi: 10.1016/j.quaint.2007. 07.006

Exley, C. (2015). A possible mechanism of biological silicification in plants. Front. Plant Sci. 6:853. doi: 10.3389/fpls.2015.00853

Gao, G., Jie, D., Liu, L., Liu, H., Gao, Z., Li, D., et al. (2018). Phytolith characteristics and preservation in trees from coniferous and broad-leaved mixed forest in an eastern mountainous area of Northeast China. Rev. Palaeobot. Palynol. 255, 43-56. doi: 10.1016/j.revpalbo.2018.05.001

Gartner, S., and Paris-Pireyre, N. (1984). La silice chez le blé (Triticum aestivum L.). comparaison entre une variété sensible et une variété resistante à la verse. J. Phys. 45, 511-514. doi: 10.1051/jphyscol:19842116

Gérard, F., Mayer, K. U., Hodson, M. J., and Ranger, J. (2008). Modelling the biogeochemical cycle of silicon in soils: application to a temperate forest ecosystem. Geochim. Cosmochim. Acta 72, 741-758. doi: 10.1016/j.gca.2007. 11.010

Hilbert, L., Neves, E. G., Pugliese, F., Whitney, B. S., Shock, M., Veasey, E., et al. (2017). Evidence for mid-Holocene rice domestication in the Americas. Nat. Ecol. Evol. 1, 1693-1698. doi: 10.1038/s41559-017-0322-4

Hodson, M. (2002) "Phytoliths," In Gathering the People, Settling the Land: The Archaeology of a Middle Thames Landscape. Anglo-Saxon to Post-Medieval, eds S. Foreman, J. Hiller, and D. Petts (Connecticut: David Brown Book Co).

Hodson, M. J. (1986). Silicon deposition in the roots, culm and leaf of Phalaris canariensis L. Ann. Bot. 58, 167-177. doi: 10.1093/oxfordjournals.aob.a08 7194

Hodson, M. J. (2016). The development of phytoliths in plants and its influence on their chemistry and isotopic composition. Implications for palaeoecology and archaeology. J. Archaeol. Sci. 68, 62-69. doi: 10.1016/j.jas.2015.09.002

Hodson, M. J. (2018) "Phytoliths in Archaeology: Chemical Aspects," In Encyclopedia of Global Archaeology, ed. C. Smith (Berlin: Springer International Publishing).

Hodson, M. J., and Hodson, M. R. (2011). Climate Change, Faith and Rural Communities. Northampton: Agriculture and Theology Project, 40.

Hodson, M. J., and Hodson, M. R. (2013) "Climate Justice: contemporary developments in science, policy, action and theology," In Carnival Kingdom Biblical Justice for Global Communities, eds M. Hoek, J. Ingleby, C. KingstonSmith, and A. Kingston-Smith (Gloucester: Wide Margin Publishers), 125-143.

Hodson, M. J., and Hodson, M. R. (2015) The Ethics of Climatic Scepticism. Cambridge: Grove Books Limited, 28.

Hodson, M. J., Parker, A. G., Leng, M. J., and Sloane, H. J. (2008). Silicon, oxygen and carbon isotope composition of wheat (Triticum aestivum L.) phytoliths: implications for palaeoecology and archaeology. J. Quat. Sci. 23, 331-339. doi: $10.1002 /$ jqs. 1176

Hodson, M. J., and Parry, D. W. (1982). The ultrastructure and analytical microscopy of silicon deposition in the aleurone layer of the caryopsis of Setaria italica (L). Beauv. Ann. Bot. 50, 221-228. doi: 10.1093/oxfordjournals. aob.a086359

Hodson, M. J., and Sangster, A. G. (1989). Subcellular localization of mineral deposits in the roots of wheat (Triticum aestivum L.). Protoplasma 15, 19-32. doi: 10.1007/BF01403298

Hodson, M. J., and Sangster, A. G. (1990). Techniques for the microanalysis of higher plants, with particular reference to silicon in cryofixed wheat tissues. Scan. Microsc. 4, 407-418.

Hodson, M. J., and Sangster, A. G. (1998). Mineral deposition in the needles of white spruce [Picea glauca (Moench.) Voss]. Ann. Bot. 82, 375-385. doi: 10.1006/anbo.1998.0694

Hodson, M. J., Sangster, A. G., and Parry, D. W. (1984). An ultrastructural study on the development of silicified tissues in the lemma of Phalaris canariensis L. Proc. R. Soc. Lond. B 222, 413-425. doi: 10.1098/rspb.1984.0074

Hodson, M. J., Sangster, A. G., and Parry, D. W. (1985). An ultrastructural study on the developmental phases and silicification of the glume of Phalaris canariensis L. Ann. Bot. 55, 649-655. doi: 10.1093/oxfordjournals.aob.a08 6944

Huang, Z., Li, Y., Jiang, P., Chang, S. X., Song, Z., Liu, J., et al. (2014). Longterm intensive management increased carbon occluded in phytolith (PhytOC) in bamboo forest soils. Sci. Rep. 4:3602. doi: 10.1038/srep03602

Ishida, S., Parker, A. G., Kennet, D., and Hodson, M. J. (2003). Phytolith analysis from the archaeological site of Kush, Ras al-Khaimah, United Arab Emirates. Quat. Res. 59, 310-321. doi: 10.1016/S0033-5894(03)00043-7
Jones, R. L., and Beavers, A. H. (1963). Some mineralogical and chemical properties of plant opal. Soil Sci. 96, 375-379. doi: 10.1097/00010694-196312000-00003

Kajale, M. D., and Eksambekar, S. P. (2007) "Phytolith Analytical Study on a Late Chalcolithic - Early Historical archaeo-stratigraphical sequence from Balathal, South Rajastan, India," In Plants, People and Places: Recent Studies in Phytolithic Analysis, eds M. Madella, and D. Zurro (Oxford: Oxbow Books), 79-91.

Katz, O. (2018). Plant silicon and phytolith research and the earth-life superdiscipline. Front. Plant Sci. 9:1281. doi: 10.3389/fpls.2018.01281

Kaufman, P. B., Dayanandan, P., Franklin, C. I., and Takeoka, Y. (1985). Structure and function of silica bodies in the epidermal system of grass shoots. Ann. Bot. 55, 487-507. doi: 10.1093/oxfordjournals.aob.a086926

Kaufman, P. B., LaCroix, J. D., Dayanandan, P., Allard, L. F., Rosen, J. J., and Bigelow, W. C. (1973) Silicification of developing internodes in the perennial scouring rush (Equisetum hyemale var. affine). Dev. Biol. 31, 124-135. doi: 10.1016/0012-1606(73)90324-2

Kaufman, P. B., LaCroix, J. D., Rosen, J. J., Allard, L. F., and Bigelow, W. C. (1972). Scanning electron microscopy and electron microprobe analysis of silicification patterns in inflorescence bracts of Avena sativa. Am. J. Bot. 59, 1018-1025. doi: 10.1002/j.1537-2197.1972.tb10180.x

Kelly, E. F., Amundson, R. G., Marino, B. D., and DeNiro, M. J. (1991). Stable isotope ratios of carbon in phytoliths as a quantitative method of monitoring vegetation and climate change. Quat. Res. 35, 222-233. doi: 10.1016/00335894(91)90069-H

Kumar, S., Milstein, Y., Brami, Y., Elbaum, M., and Elbaum, R. (2017a) Mechanism of silica deposition in sorghum silica cells. New Phytol. 213, 791-798. doi: 10.1111/nph.14173

Kumar, S., Soukup, M., and Elbaum, R. (2017b). Silicification in grasses: variation between different cell types. Front. Plant Sci. 8:438

Laue, M., Hause, G., Dietrich, D., and Wielage, B. (2007). Ultrastructure and microanalysis of silica bodies in Dactylis glomerata L. Microchim. Acta 156, 103-107. doi: 10.1007/s00604-006-0593-y

Li, Z., Song, Z., and Jiang, P. (2013a). Biogeochemical sequestration of carbon within phytoliths of wetland plants: a case study of Xixi wetland, China. Chin. Sci. Bull. 58, 2480-2487. doi: 10.1007/s11434-013-5785-3

Li, Z., Song, Z., Parr, J. F., and Wang, H. (2013b). Occluded C in rice phytoliths: implications to biogeochemical carbon sequestration. Plant Soil 370, 615-623. doi: 10.1007/s11104-013-1661-9

Lux, A., Luxova, M., Abe, J., Morita, S., and Inanaga, S. (2003). Silicification of bamboo (Phyllostachys heterocycla Mitf.) root and leaf. Plant Soil 255, 85-91. doi: 10.1023/A:1026157424794

Madella, M., Alexandre, A., and Ball, T. (2005). International Code for phytolith nomenclature 1.0. Ann. Bot. 96, 253-260. doi: 10.1093/aob/mci172

Mulholland, S. C., and Prior, C. (1993) “AMS radiocarbon dating of phytoliths," In Current Research in Phytolith Analysis: Applications in Archaeology and Paleoecology, MASCA Research Papers in Science and Archaeology, eds D. M. Pearsall, and D. R. Piperno (Pennsylvania, PA: University of Pennsylvania Museum), 21-23.

Park, D.-A, Wi, S. G., Lee, K. H., Singh, A. P., Yoon, T.-H., and Yoon, S. K. (2003). Characterization of anatomical features and silica distribution in rice husk using microscopic and micro-analytical techniques. Biomass Bioenerg. 25, 319-327. doi: 10.1016/S0961-9534(03)00014-X

Parker, A. G., Eckersley, L., Smith, M. M., Goudie, A. S., Stokes, S., Ward, S., et al. (2004). Holocene vegetation dynamics in the northeastern Rub' al-Khali desert, Arabian Peninsula: a phytolith, pollen and carbon isotope study. J. Quat. Sci. 19, 665-676. doi: 10.1002/jqs.880

Parr, J. F., and Sullivan, L. A. (2011). Phytolith occluded carbon and silica variability in wheat cultivars. Plant Soil 342, 165-171. doi: 10.1007/s11104-010-0680-z

Parr, J., Sullivan, L., Chen, B., Ye, G., and Zheng, W. (2010). Carbon biosequestration within the phytoliths of economic bamboo species. Glob. Change Biol. 16, 2661-2667 doi: 10.1111/j.1365-2486.2009.02118.x

Parr, J., Sullivan, L., and Quirk, R. (2009). Sugarcane phytoliths: encapsulation and sequestration of a long-lived carbon fraction. Sugar Tech. 11, 17-21. doi: 10.1007/s12355-009-0003-y

Parr, J. F., Dolic, V., Lancaster, G., and Boyd, W. E. (2001). A microwave digestion method for the extraction of phytoliths from herbarium specimens. Rev. Palaeobot. Palynol. 116, 203-212. doi: 10.1016/S0034-6667(01)00089-6

Parr, J. F., and Sullivan, L. A. (2005). Soil carbon sequestration in phytoliths. Soil Biol. Biochem. 37, 117-124. doi: 10.1016/j.soilbio.2004.06.013 
Parr, J. F., and Sullivan, L. A. (2014). Comparison of two methods for the isolation of phytolith occluded carbon from plant material. Plant Soil 374, 45-53. doi: 10.1007/s11104-013-1847-1

Parry, D. W., Hodson, M. J., and Newman, R. H. (1985). The distribution of silicon deposits in the fronds of Pteridium aquilinum L. Ann. Bot. 55, 77-83. doi: 10.1093/oxfordjournals.aob.a086880

Parry, D. W., Hodson, M. J., and Sangster, A. G. (1984). Some recent advances in studies of silicon in higher plants. Philos. Trans. R. Soc. Lond. B 304, 537-549. doi: $10.1098 /$ rstb.1984.0045

Perry, C. C., Williams, R. J. P., and Fry, S. C. (1987). Cell wall biosynthesis during silicification of grass hairs. J. Plant Physiol. 126, 437-448. doi: 10.1016/S01761617(87)80028-7

Piperno, D. R. (2006). Phytoliths: A Comprehensive Guide for Archaeologists and Paleoecologists. Oxford: Rowman Altamira, 239.

Powlson, D. S., Whitmore, A. P., and Goulding, K. W. (2011). Soil carbon sequestration to mitigate climate change: a critical re-examination to identify the true and the false. Eur. J. Soil Sci. 62, 42-55. doi: 10.1111/j.1365-2389.2010. 01342.x

Prasad, V., Strömberg, C. A. E., and Alimohammadian, H., and Sahni, A. (2005). Dinosaur coprolites and the early evolution of grasses and grazers. Science 310, 1177-1180. doi: 10.1126/science. 1118806

Puppe, D., Höhn, A., Kaczorek, D., Wanner, M., Wehrhan, M., and Sommer, M. (2017). How big is the influence of biogenic silicon pools on short-term changes in water-soluble silicon in soils? Implications from a study of a 10-year-old soil-plant system. Biogeosciences 14, 5239-5252. doi: 10.5194/bg-14-5239-2017

Reyerson, P. E., Alexandre, A., Harutyunyan, A., Corbineau, R., Martinez De La Torre, H. A., Badeck, F., et al. (2016). Unambiguous evidence of old soil carbon in grass biosilica particles. Biogeosciences 13, 1269-1286. doi: 10.5194/bg-131269-2016

Rosen, A. M. (1993) "Phytolith evidence for early cereal exploitation in the Levant," In Current Research in Phytolith Analysis: Applications in Archaeology and Paleoecology, MASCA Research Papers in Science and Archaeology, eds D. M. Pearsall, and D. R. Piperno (Pennsylvania, PA: University of Pennsylvania Museum), 161-171.

Rosen, A. M., and Weiner, S. (1994). Identifying ancient irrigation: a new method using opaline phytoliths from emmer wheat. J. Archaeol. Sci. 21, 125-132. doi: 10.1006/jasc.1994.1013.

Sangster, A. G., Hodson, M. J., Parry, D. W., and Rees, J. A. (1983). A developmental study of silicification in the trichomes and associated epidermal structures of the inflorescence bracts of the grass, Phalaris canariensis L. Ann. Bot. 52, 171-197. doi: 10.1093/oxfordjournals.aob.a086563

Sangster, A. G., and Parry, D. W. (1976). The ultrastructure and electronprobe microassay of silicon deposits in the endodermis of the seminal roots of Sorghum bicolor (L.) Moench. Ann. Bot. 40, 447-459. doi: 10.1093/ oxfordjournals.aob.a085153

Santos, G., Alexandre, A., Coe, H., Reyerson, P., Southon, J., and De Carvalho, C. (2010). The phytolith ${ }^{14} \mathrm{C}$ puzzle: a tale of background determinations and accuracy tests. Radiocarbon 52, 113-128. doi: 10.1017/S0033822200045070

Santos, G. M., and Alexandre, A. (2017). The phytolith carbon sequestration concept: fact or fiction? A comment on "occurrence, turnover and carbon sequestration potential of phytoliths in terrestrial ecosystems by Song et al. doi: 10.1016/j.earscirev.2016.04.007". Earth Sci. Rev. 164, 251-255. doi: 10.1016/j. earscirev.2016.11.005

Sola-Rabada, A., Sahare, P., Hickman, G. J., Vasquez, M., del Rio, J. A., Canham, L. T., et al. (2018). Biogenic porous silica and silicon sourced from Mexican Giant Horsetail (Equisetum myriochaetum) and their application as supports for enzyme immobilization. Colloids Surf. B Biointerfaces 166, 195-202. doi: 10.1016/j.colsurfb.2018.02.047

Song, Z., Liu, H., Li, B., and Yang, X. (2013). The production of phytolith-occluded carbon in China's forests: implications to biogeochemical carbon sequestration. Glob. Change Biol. 19, 2907-2915. doi: 10.1111/gcb.12275

Song, Z., Liu, H., Si, Y., and Yin, Y. (2012a). The production of phytoliths in China's grasslands: implications to the biogeochemical sequestration of atmospheric $\mathrm{CO}_{2}$. Glob. Change Biol. 18, 3647-3653. doi: 10.1111/gcb.12017

Song, Z., Wang, H., Strong, P. J., Li, Z., and Jiang, P. (2012b). Plant impact on the coupled terrestrial biogeochemical cycles of silicon and carbon: implications for biogeochemical carbon sequestration. Earth Sci. Rev. 115, 319-331. doi: 10.1016/j.earscirev.2012.09.006

Song, Z., Liu, H., Strömberg, C. A. E., Yang, X., and Zhang, X. (2017). Phytolith carbon sequestration in global terrestrial biomes. Sci. Tot. Environ. 603-604, 502-509. doi: 10.1016/j.scitotenv.2017.06.107.

Song, Z., McGrouther, K., and Wang, H. (2016). Occurrence, turnover and carbon sequestration potential of phytoliths in terrestrial ecosystems. Earth Sci. Rev. 158, 19-30. doi: 10.1016/j.earscirev.2016.04.007

Song, Z., Wang, H., Strong, P. J., and Guo, F. (2014). Phytolith carbon sequestration in China's croplands. Eur. J. Agron. 53, 10-15. doi: 10.1016/j.eja.2013. 11.004

Strömberg, C., Dunn, R., Harris, E., and Crifò, C. (2018) "Phytoliths in Paleoecology," In Methods in Paleoecology: Reconstructing Cenozoic Terrestrial Environments and Ecological Communities, eds D. A. Croft, D. F. Su, and S. W. Simpson (Berlin: Springer), 235-287. doi: 10.1007/978-3-319-94265-0_12

Strömberg, C. A. E., and McInerney, F. A. (2011). The Neogene transition from C3 to C4 grasslands in North America: assemblage analysis of fossil phytoliths. Paleobiology 37, 50-71. doi: 10.1666/09067.1

Struyf, E., Smis, A., Van Damme, S., Garnier, J., Govers, G., Van Wesemael, B., et al. (2010). Historical land use change has lowered terrestrial silica mobilization. Nat. Commun. 1:129

Sun, X., Liu, Q., Zhao, G., Chen, X., Tang, T., and Xiang, Y. (2017). Comparison of phytolith-occluded carbon in 51 main cultivated rice (Oryza sativa) cultivars of China. RSC Adv. 7, 54726-54733. doi: 10.1039/C7RA10685H

Thummel, R. V., Brightly, W. H., and Strömberg, C. A. E. (2018). Evolution of phytolith deposition in modern bryophytes, and implications for the fossil record and influence on silica cycle in early land plant evolution. New Phytol. 221, 2273-2285. doi: 10.1111/nph.15559

Thurston, E. L. (1974). Morphology, fine structure, and ontogeny of the stinging emergence of Urtica dioica. Am. J. Bot. 61, 809-817. doi: 10.1002/j.1537-2197. 1974.tb12306.x

Turpault, M.-P., Calvaruso, C., Kirchen, G., Redon, P.-O., Cochet, C. (2018). Contribution of fine tree roots to the silicon cycle in a temperate forest ecosystem developed on three soil types. Biogeosciences 15, 2231-2249. doi: 10.5194/bg-15-2231-2018

Watteau, F., and Villemin, G. (2001). Ultrastructural study of the biogeochemical cycle of silicon in the soil and litter of a temperate forest. Eur. J. Soil Sci. 53, 385-396. doi: 10.1046/j.1365-2389.2001.00391.x

Wilding, L. P. (1967). Radiocarbon dating of biogenetic opal. Science 156, 66-67. doi: $10.1126 /$ science.156.3771.66

Wu, Y., You, H.-L., and Li, X.-Q. (2018). Dinosaur-associated Poaceae epidermis and phytoliths from the Early Cretaceous of China. Nat. Sci. Rev. 5, 721-727. doi: $10.1093 / \mathrm{nsr} / \mathrm{nwx} 145$

Yin, J., Yang, X., and Zheng, Y. (2014). Influence of increasing combustion temperature on the AMS ${ }^{14} \mathrm{C}$ dating of modern crop phytoliths. Sci. Rep. 4:6511. doi: 10.1038/srep06511

Zhang, J., Lu, H., Wu, N., Li, F., Yang, X., Wang, W., et al. (2010). Phytolith evidence for rice cultivation and spread in mid-late neolithic archaeological sites in central North China. Boreas 39, 592-602.

Zhang, X., Song, Z., Hao, Q., Wang, Y., Ding, F., and Song, A. (2019). Phytolithoccluded carbon storages in forest litter layers in Southern China: implications for evaluation of long-term forest carbon budget. Front. Plant Sci. 10:581

Zuo, X. X., and Lü, H. Y. (2011). Carbon sequestration within millet phytoliths from dry-farming of crops in China. Chin. Sci. Bull. 56, 3451-3456. doi: 10. 1007/s11434-011-4674-x

Conflict of Interest Statement: The author declares that the research was conducted in the absence of any commercial or financial relationships that could be construed as a potential conflict of interest.

Copyright (c) 2019 Hodson. This is an open-access article distributed under the terms of the Creative Commons Attribution License (CC BY). The use, distribution or reproduction in other forums is permitted, provided the original author(s) and the copyright owner(s) are credited and that the original publication in this journal is cited, in accordance with accepted academic practice. No use, distribution or reproduction is permitted which does not comply with these terms. 